\title{
Upper Eocene coal and coaly shale in the Central Myanmar Basin: Origin of organic matter and the effect of weathering
}

\author{
EI MON HAN, YOSHIKAZU SAMPEI* and BARRY ROSER \\ Department of Geoscience, Graduate School of Science and Engineering, Shimane University, \\ 1060 Nishikawatsu, Matsue 690-8504, Japan
}

(Received November 1, 2013; Accepted January 13, 2014)

\begin{abstract}
Extensive coals and coaly shales were deposited at the western margin of the Central Myanmar Basin (CMB) during the Late Eocene. Carbon, nitrogen and sulfur (CNS) elemental analyses, vitrinite reflectance, Rock-Eval pyrolysis, biomarker analyses and $\delta^{13} \mathrm{C}$ measurements were made of eight coal and coaly shale samples from the Pondaung and Yaw Formations. Moderate weathering was recognized in three coaly shales, as manifest by microscopic cracks, holes, and rim structures in vitrinite. A sample pair of fresh and weathered coaly shale collected from the same seam showed that HI, $\mathrm{Pr} / \mathrm{Ph}$ ratio, and concentration of PAHs and long chain $n$-alkanes $\left(>n-\mathrm{C}_{20}\right)$ bonded to kerogen in the coaly shales decreased drastically due to weathering, while OI increased. These results suggest that hydrocarbon generation potential of the coaly shale as an oil/gas source rock decreased to about one tenth by the weathering, whereas the free $n$-alkanes, biomarkers such as steranes and triterpanes, and $\delta^{13} \mathrm{C}$ ratios of kerogen were not affected.

Facies change from the coaly shale layers (Phase-I) to the coal layers (Phase-II) was accompanied by variations in origin of the organic matter. The source of the organic matter was mainly terrestrial herbaceous vegetation and/or aquatic plants, deposited in oxic to oxygen-poor peat swamps associated with an estuarine/fluvial-deltaic setting. Phase-I is relatively rich in gymnosperm biomarkers such as retene and 1,7-dimethylphenanthrene (DMP), whereas Phase-II shows an increase in angiosperm proxies such as oleanane content and oleanane/ $\mathrm{C}_{30}$ hopane ratio, with $\delta^{13} \mathrm{C}$ values ranging from $-24.6 \%$ to $-26.5 \%$. Based on HI values of unweathered samples, Phase-I is characterized by type II-III kerogen, while Phase-II contains type III kerogen. Higher values of $\mathrm{HI}, \mathrm{Pr} / \mathrm{Ph}$ ratios, $n-\mathrm{C}_{29} / n-\mathrm{C}_{19}$ alkane ratios $(>1.5)$, and higher concentrations of conifer-derived 1,7-DMP in Phase-I suggest a significant contribution from material of resinous vascular plant origin. High Fluoranthene/(Fluoranthene+Pyrene) ratio in the uppermost coal suggests occurrence of wildfire, probably related to a dry climate experienced in Phase-II. Unweathered CMB samples show good source rock quality, with potential generation of liquid/gas hydrocarbons.
\end{abstract}

Keywords: Upper Eocene, coal and coaly shale, depositional environment, weathering, paleovegetation, Central Myanmar Basin

\section{INTRODUCTION}

Several seams of coal and coaly shale in Late Eocene formations are exposed in the Central Myanmar Basin (CMB) (Bender, 1983). These thin carbonaceous seams are correlated with coal deposits in the Eastern Highlands, the Inner-Myanmar Tertiary Basin and the Arakan Coastal Area, where there is a limited commercial production. However, no detailed geochemical studies have been made of the Late Eocene coals and coaly shales. Furthermore, the organic geochemical characteristics of Myanmar sedimentary/carbonaceous materials have not yet been investigated in any depth. A report by Curiale et al. (1994) on the CMB oil family is the only available published work on organic geochemistry in Myanmar that we are aware

*Corresponding author (e-mail: sampei@riko.shimane-u.ac.jp)

Copyright $@ 2014$ by The Geochemical Society of Japan. of. Based on the composition of hydrocarbons, these authors speculated that the Eocene coals in the CMB were one of the sources for the oils/gas found within the basin. Nevertheless, source rock analyses to determine hydrocarbon generation potential of sediments including coals and/or coaly shales have not yet been made.

In this study, we focus on the characteristics of Late Eocene coals and coaly shale-bearing formations deposited along the western margin of the CMB (Fig. 1). Although the coal seams in the western margin of the CMB are generally thin $(5-150 \mathrm{~cm})$, several thicker seams have been found in the central part of the Inner-Myanmar Tertiary Basin (IMTB) (Bender, 1983). The Late Eocene sequence in the CMB is divided into two lithostratigraphic formations; the Pondaung sandstone (Lowermost Late Eocene) and the overlying Yaw shale (Uppermost Late Eocene). We found four coals and four coaly shale beds in the Pondaung and Yaw formations (Fig. 1a) during a detailed geological survey of our study area in the west- 

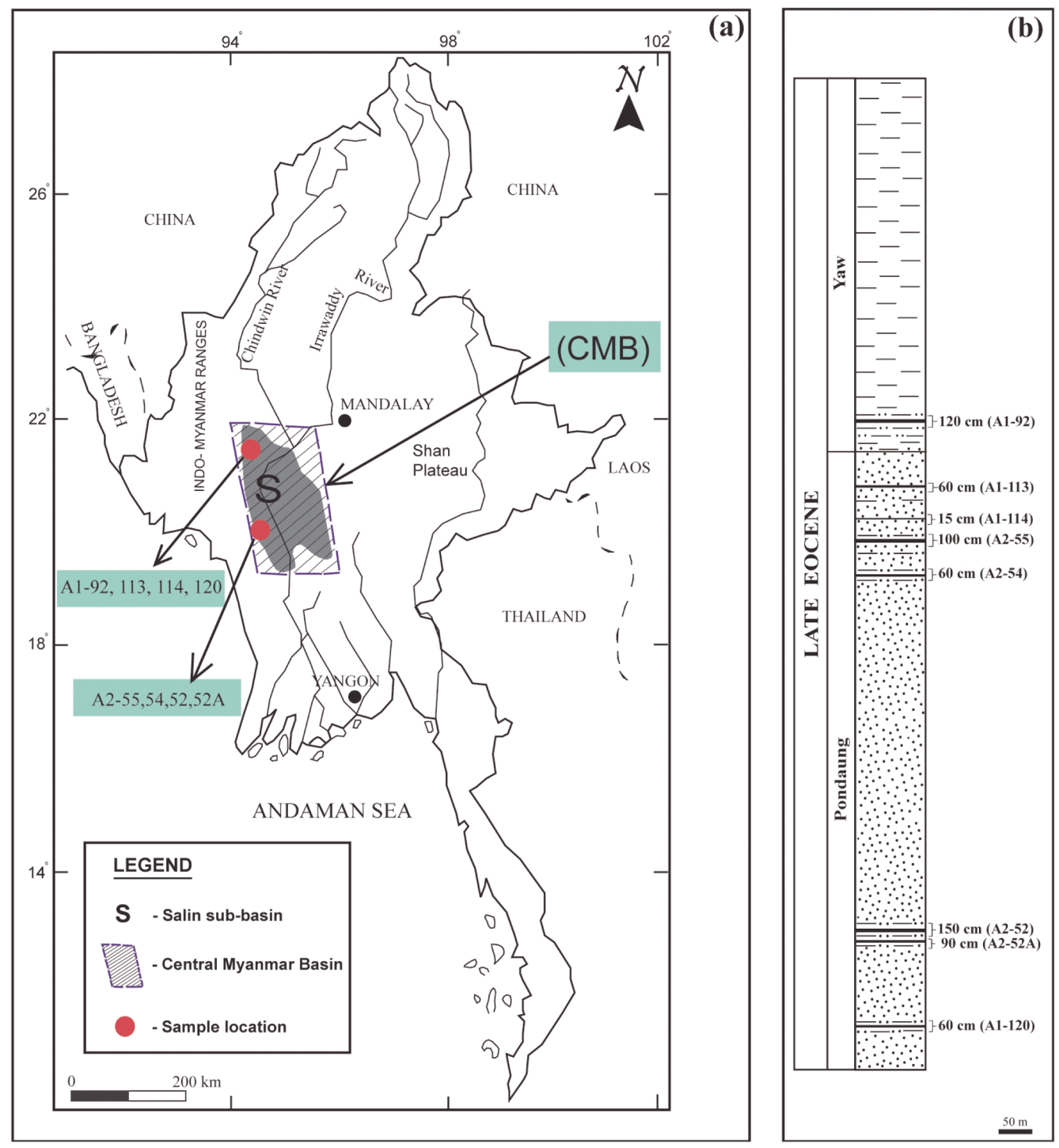

Fig. 1. (a) Location of the study area in the Central Myanmar Basin (CMB) and Salin sub-basin (CMB and $S$ boundaries from Pivnik et al., 1998), and (b) lithostratigraphic column of the study area in the western margin of the CMB, Myanmar.

ern part of the CMB (Fig. 1b). Vitrinite reflectance, RockEval pyrolysis, elemental analyses, biomarker analyses and $\delta^{13} \mathrm{C}$ measurements were made of these Late Eocene coals and coaly shales. The effects of tropical weathering on the characteristics of coals and coaly shales were also studied. This is the first detailed organic geochemical description of the carbonaceous rocks of Myanmar.

\section{GeOlOGical SETTING AND STRATIGRAPHY}

Geomorphologically, Myanmar can be sub-divided into four major tectonic provinces: (1) Shan Plateau (Eastern Highlands), (2) Central Cenozoic Belt, (3) Western Fold Belt (i.e., the Indo-Myanmar Ranges and Arakan
Yoma) and (4) the Arakan Coastal Plain, from east to west (Fig. 1a). In early Tertiary time, the Shan Plateau formed a land mass in the east, and the Arakan Yoma comprised a narrow strip of land in the west (Chhibber, 1934). The long and narrow lowland between the two was known as the IMTB or Burmese Gulf (Bender, 1983). The IMTB was underlain by Mesozoic deep-water sediments and older metamorphic basements, and was occupied by the sea until the Late Tertiary period, by which time it had filled with Tertiary clastic sediments (Chhibber, 1934; Bender, 1983).

The CMB, which has been known as the Salin subbasin (Fig. 1a), formed as a subsiding sub-basin within the IMTB. The total stratigraphic thickness of the CMB 

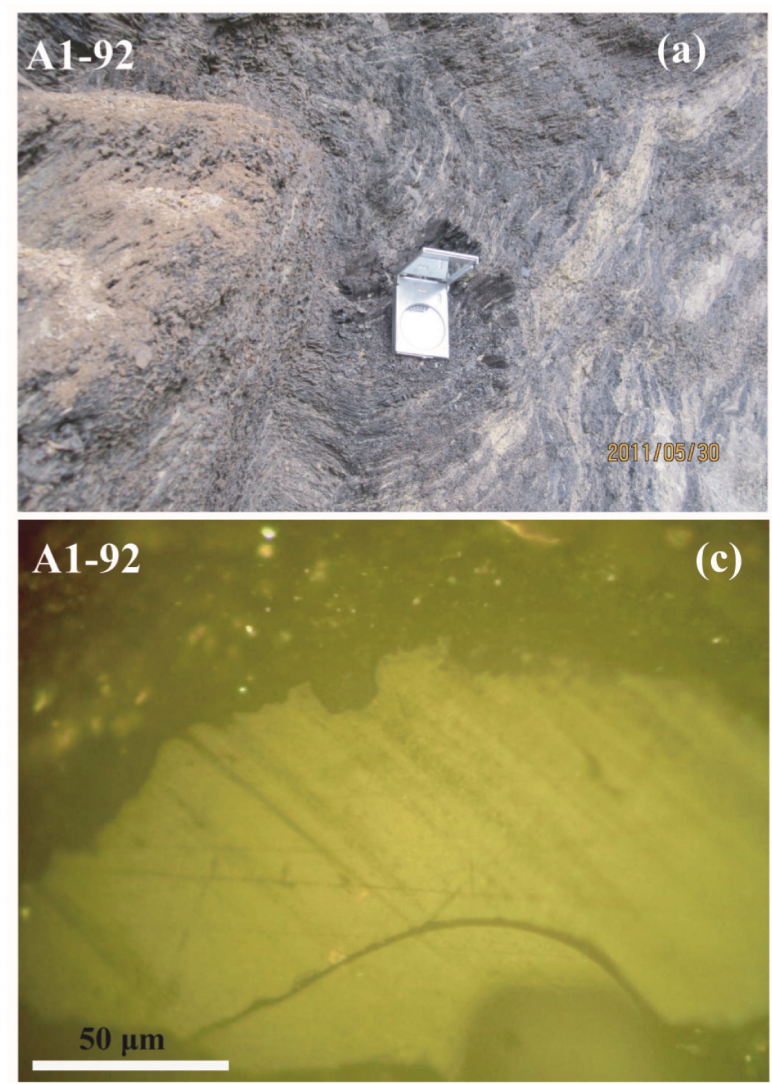
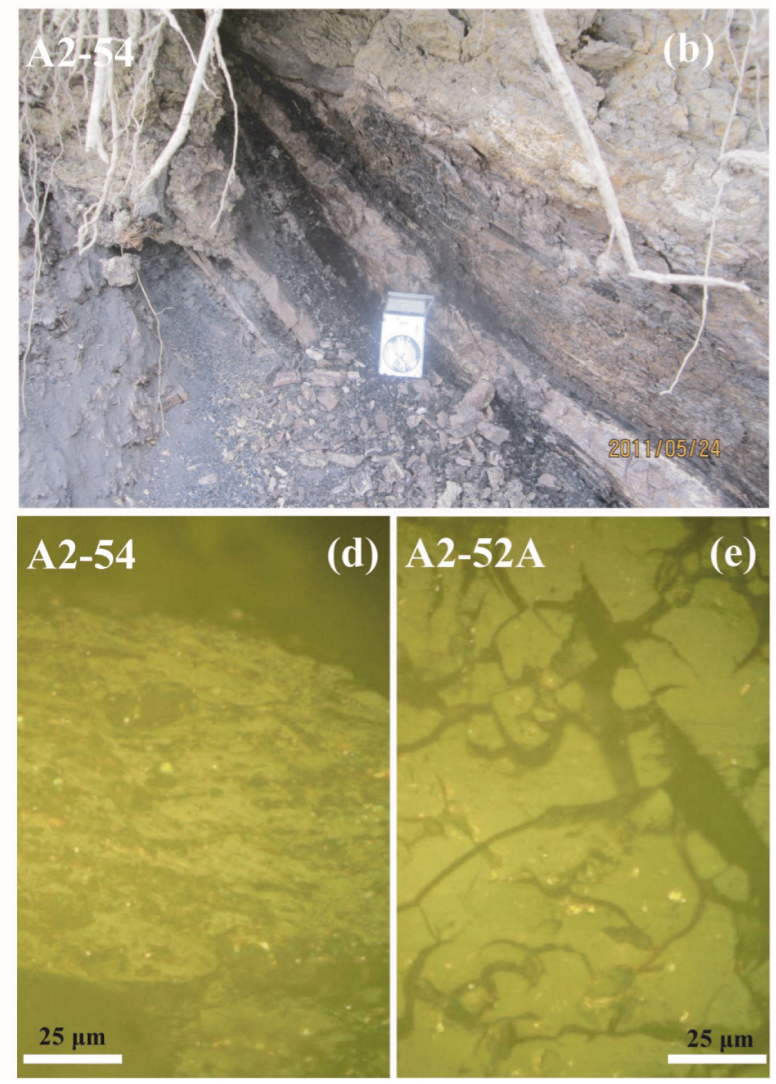

Fig. 2. Outcrop photographs of (a) unweathered coal and (b) weathered coaly shale; photomicrographs of (c) Al-92, illustrating thin micro-fissures in vitrinite (d) A2-54, dark oxidized rims along irregular micro-fissures in vitrinite (e) A2-52A, showing dark oxidized rims along irregular micro-fissures in vitrinite particles.

succession is very thick, up to $19 \mathrm{~km}$ (Tun, 1968; Myint and Soe, 1977). The great depth of the CMB is considered to be due to tectonic subsidence (i.e., oblique subduction of the Indian oceanic plate underneath the Myanmar micro-plate) by sediment loading (Hall and Morley, 2004). The CMB is a complex fore-arc/back-arc basin, and is situated between a major right-lateral strike slip fault in the east, and the obliquely converging India plate beneath the Myanmar (Burma) micro-plate to the west (Pivnik et al., 1998).

The Tertiary succession in Myanmar is characterized by fluvio-deltaic sediments in the north, and by transgressive shallow marine shales in the south (Stamp, 1934). The CMB is one of the largest petroliferous onshore subbasins within the IMTB. Hydrocarbon seeps occur locally along both the eastern and western margins of the CMB. Tertiary coal seams are widely distributed in the CMB and other sub-basins of the IMTB. Coals of Eocene age can be found in Kyaukset village in Minbu district, and in Tazu and Letpanhla villages in Pakokku district within the CMB. Coal seams in this district generally vary from 1.2 to $2.1 \mathrm{~m}$ in thickness (Bender, 1983).
The present study area is located in the western margin of the CMB (Fig. 1). The lower part of the upper Eocene Pondaung Formation (Fig. 1b) is composed mainly of thick-bedded to massive sandstones interbedded with thinly-bedded grey shales, siltstones, and coal seams. The thickness of sandstone in this formation reflects a sea level regression (Chhibber, 1934). Seams of brownish to black coals $15-150 \mathrm{~cm}$ in thickness occur in the upper part of the Pondaung Formation in the study area. The Pondaung Formation is interpreted to have accumulated in swampy brackish-water conditions and in near-shore fluvial environments, as evidenced by fossils and sedimentary facies (Myint and Soe, 1977). Black coal layers $c a .1 \mathrm{~m}$ in thickness occur in the lower part of the overlying upper Eocene Yaw Formation. The Yaw Formation (Fig. 1b) consists mainly of nodular, bluish-grey shales and fine-grained sandstones with coal seams.

\section{SAMPLES AND METHODS}

\section{Samples}

Four coals (samples A1-92, A1-113, A1-114, and A2- 
55) and four coaly shales (A2-54, A2-52, A2-52A, and A1-120) were collected from Late Eocene Pondaung and Yaw outcrops along the western margin of the CMB (Fig. $1 b)$. The four coal seams were deposited after sedimentation of underlying coaly shale layers. This sedimentary sequence was first found in the present study. Therefore, the sedimentary facies are divisible into two phases: a lower part consisting of the coaly shales (Phase-I) and an upper part containing the coal layers (Phase-II) (Fig. 2). Each coal and coaly shale seam ranged from 15 to 150 $\mathrm{cm}$ in thickness. Based mainly on microscopic observation, we detected signs of weathering in three of the coaly shale samples (A2-54, A2-52A and A1-120).

\section{Elemental analysis ( $C, N$ and $S$ )}

Each sample was prepared by air drying, cleaned with ethanol to remove any surface contamination, and powdered in an iron pestle and mortar. Powdered samples were placed in silver capsules, pre-treated with 1M HCL to remove carbonate, and then dried at room temperature. Samples dried at $110^{\circ} \mathrm{C}$ for $45 \mathrm{~min}$. were then placed in tin capsules and sealed. Total carbon, sulfur and nitrogen contents were determined using an EA1108 Elemental Analyzer (FISONS Co. Ltd.). Ash contents of the coals were determined by heating in a muffle furnace at $850^{\circ} \mathrm{C}$ for 2 hours.

\section{Microscopic observation and vitrinite reflectance}

Vitrinite reflectance $\left(R_{o}\right)$ measurements were made on all samples. Coal and coaly shale chips (ca. $2 \mathrm{~mm}$ ) were embedded in an epoxy resin which was allowed to set for $24 \mathrm{hrs}$. The mounts were then polished using waterlubricated silicon carbide paper of different grades (\#320, \#600), and finished to a highly reflecting surface using finer grade alumina powders. Reflectance measurements were made under oil immersion in $546 \mathrm{~nm}$ reflected light, using a Lambda Vision-OLYMPUS microscope equipped with a TFCAM7000F-LA100USW spectrograph system.

\section{Rock-Eval pyrolysis}

Rock-Eval analysis was carried out to evaluate the potential hydrocarbon generation and maturity of the Late Eocene samples, using a Rock-Eval 6. Powdered whole rock samples $(6-100 \mathrm{mg})$ were heated from $300^{\circ} \mathrm{C}$ to $650^{\circ} \mathrm{C}$ in a helium flow. The amounts of hydrocarbons released from organic matter were then used to determine hydrogen index (HI mg HC/g TOC), oxygen index (OI $\mathrm{mg} \mathrm{CO} / \mathrm{g}$ TOC) and temperature of hydrocarbon maximum generation $\left(T_{\max }\right)$. This analysis was performed by JAPEX Research Center.

\section{Biomarker analyses and pyrolysis-GC-MS}

Extractions were made of coals and coaly shale samples weighing $c a \cdot 1.5-5 \mathrm{~g}$, depending on their total or- ganic carbon contents. Extracts were made in a Soxhlet extractor, using a 9:1 mixture of dichloromethane (DCM) and methanol $\left(\mathrm{CH}_{3} \mathrm{OH}\right)$ for $120 \mathrm{hrs}$ for the coals (23.1$57.6 \mathrm{wt} \%$ TOC) and $72 \mathrm{hrs}$ for the coaly shales (2.08$8.58 \mathrm{wt} \%$ TOC). Activated copper was used to remove elemental sulfur from the solvents during the extraction. After a first evaporation of the solvent, the extracts were transferred from the flask to a beaker by dissolution with a little DCM-methanol solvent, and then dried overnight in a draft hood at room temperature. The dried extracts were then dissolved in $n$-hexane and placed on a thin layer chromatographic (TLC) plate for compound class separation. The aliphatic and aromatic fractions from TLC were analyzed using a GC-MS (QP2010: Shimadzu Co. Ltd.) equipped with a $30 \mathrm{~m}$ capillary column $(\mathrm{m} / \mathrm{z} 50$ 850; DB-5MS, $0.25 \mathrm{~mm}$ i.d., $0.25 \mu \mathrm{m}$ film (5\% phenyl methylpolysiloxane) thickness: Agilent Technologies), using electron impact ionization $(70 \mathrm{eV})$. The $\mathrm{GC}$ oven temperature was held at $50^{\circ} \mathrm{C}$ for $5 \mathrm{~min}$, programmed from 50 to $300^{\circ} \mathrm{C}$ at a rate of $8^{\circ} \mathrm{C} \mathrm{min}^{-1}$, and then held at $300^{\circ} \mathrm{C}$ for $30 \mathrm{~min}$. Helium was used as the carrier gas. $n$-Tetracosane, cholestane and polycyclic aromatic hydrocarbons (PAHs) Solution Mix (Accu Standard Inc., Z-01317) were used as external standards for differing compound groups in the hydrocarbon fractions. Individual compounds were identified by comparison of retention times with standard mixtures and mass spectra with previous literature and published work from our laboratory. Identification of PAHs was performed by comparison of GC retention times, mass spectra with published data and standard PAHs. In this study, the PAHs quantified were cadalene (Cad), phenanthrene (Phe), fluoranthene (Fla), pyrene (Py), benzo (a) anthracene (BaAn), chrysene/ triphenylene (Chry+Tpn), benzofluoranthenes (Bflas), benzo[e]pyrenes (BePy), benzo[a]pyrenes (BaPy), perylene (Pery), indeo[1,2,3-cd] pyrene (InPy), benzo (ghi) perylene (BghiP), coronene (Cor) and retene (Ret). Selected PAHs were monitored at $m / z 183$ (Cad), $m / z 178$ (P, An), m/z 202 (Fla, Py), m/z 291 (Ret), m/z 228 (BaAn, Chry), $m / z 252$ (Bflas, BePy, BaPy, Pery), m/z 276 (InPy, BghiP), and $\mathrm{m} / \mathrm{z} 300$ (Cor). Relative abundances (\%) and concentrations $(\mu \mathrm{g} / \mathrm{g}$ TOC) were calculated by comparing the TIC (total ion current) chromatogram area to the standard area.

For Py-GC-MS, samples were pyrolysed at $600^{\circ} \mathrm{C}(30$ sec.), after removal of free hydrocarbons and nonhydrocarbons using the 9:1 DCM-methanol solvent, using a double-shot pyrolyser (PY-2020D) connected to a GC-17A gas chromatograph coupled with a mass spectrometer $(\mathrm{m} / \mathrm{z}$ 35-850; Shimadzu GC-MS QP5050A). The GC oven was operated with a $30 \mathrm{~m}$ fused silica column (DB-5MS, $0.25 \mathrm{~mm}$ i.d., $0.25 \mu \mathrm{m}$ film (5\% phenyl methylpolysiloxane) thickness: Agilent Technologies). Helium was used as the carrier gas. The GC oven tem- 
Table 1. (a) TOC and TS contents, C/N and C/S ratios, vitrinite reflectance, Rock-Eval pyrolysis parameters and carbon isotope values for Upper Eocene coals and coaly shales from the Central Myanmar Basin, Myanmar. Coal Al-92 is from the Yaw Formation; all others from Pondaung Formation, in ascending stratigraphic order from left to right. (b) Molecular concentrations and ratios.

\begin{tabular}{|c|c|c|c|c|c|c|c|c|}
\hline \multirow{2}{*}{$\begin{array}{l}\text { Group } \\
\text { Sample }\end{array}$} & \multicolumn{4}{|c|}{ Phase-I coaly shales } & \multicolumn{4}{|c|}{ Phase-II coals } \\
\hline & $* \mathrm{~A} 1-120$ & $* \mathrm{~A} 2-52 \mathrm{~A}$ & A2-52 & $* A 2-54$ & A2-55 & A1-114 & A1-113 & A1-92 \\
\hline \multicolumn{9}{|c|}{ (a) TOC, TS, C/N, C/S, $R_{o}$, Rock-Eval pyrolysis parameters and carbon isotope values } \\
\hline TOC $(w t \%)$ & 7.18 & 2.08 & 8.58 & 7.36 & 31.3 & 57.6 & 23.1 & 26.3 \\
\hline TS (wt $\%)$ & 0.08 & 0.13 & 1.14 & 0.48 & 0.19 & 0.09 & 0.47 & 3.95 \\
\hline $\mathrm{C} / \mathrm{N}$ & 19.8 & 16.0 & 30.6 & 26.3 & 39.9 & 66.8 & 39.3 & 49.7 \\
\hline $\mathrm{C} / \mathrm{S}$ & 95.4 & 16.1 & 7.5 & 15.5 & 167 & 612 & 49.0 & 6.60 \\
\hline$R_{o}(\%)$ & 0.36 & 0.30 & 0.39 & 0.33 & 0.42 & 0.26 & 0.28 & 0.29 \\
\hline$T_{\max }\left({ }^{\circ} \mathrm{C}\right)$ & 442 & 451 & 425 & 435 & 429 & 413 & 421 & 422 \\
\hline $\mathrm{S}_{1}(\mathrm{mg} \mathrm{HC} / \mathrm{g})$ & 0.07 & 0.01 & 0.23 & 0.03 & 0.71 & 0.36 & 3.86 & 1.92 \\
\hline $\mathrm{S}_{2}(\mathrm{mg} \mathrm{HC} / \mathrm{g})$ & 1.87 & 0.25 & 16.4 & 1.46 & 52.0 & 57.3 & 32.6 & 37.4 \\
\hline $\mathrm{HI}$ (mg HC/g TOC) & 26 & 12 & 191 & 20 & 166 & 100 & 141 & 142 \\
\hline $\mathrm{OI}(\mathrm{mg} \mathrm{CO} / \mathrm{g}$ TOC $)$ & 144 & 212 & 28 & 137 & 44 & 40 & 107 & 73 \\
\hline PI & 0.04 & 0.04 & 0.01 & 0.02 & 0.01 & 0.01 & 0.11 & 0.05 \\
\hline$\delta^{13} \mathrm{C}(\% \circ$ vs. PDB $)$ & -24.6 & -25.7 & -26.0 & -24.5 & -25.5 & -24.8 & -26.5 & -26.5 \\
\hline \multicolumn{9}{|l|}{ (b) Biomarker compositions } \\
\hline $\mathrm{Pr} / \mathrm{Ph}$ & 0.24 & 0.69 & 9.09 & 0.23 & 4.63 & 0.71 & 3.16 & 2.37 \\
\hline $\mathrm{Pr} / n-\mathrm{C}_{17}$ & 4.75 & 7.34 & 5.44 & 1.87 & 9.86 & 4.80 & 7.81 & 7.03 \\
\hline CPI & 1.76 & 2.25 & 2.22 & 1.29 & 2.09 & 1.46 & 1.16 & 2.11 \\
\hline$n-\mathrm{C}_{29} / n-\mathrm{C}_{19}$ & 5.41 & 1.84 & 1.73 & 0.07 & 0.67 & 0.85 & 0.35 & 1.26 \\
\hline$n-\mathrm{C}_{20-25} /$ total $n$-alkanes & 0.32 & 0.37 & 0.32 & 0.69 & 0.47 & 0.65 & 0.48 & 0.55 \\
\hline Sterane $C_{29} 20 S /(20 S+20 R)$ & 0.03 & 0.12 & 0.17 & 0.06 & 0.07 & 0.28 & 0.37 & 0.27 \\
\hline $\mathrm{Ts} /(\mathrm{Ts}+\mathrm{Tm})$ & 0.33 & 0.46 & 0.56 & 0.41 & 0.45 & 0.54 & 0.65 & 0.37 \\
\hline Oleanane/ $\mathrm{C}_{30}$ hopane & 0.12 & 0.20 & 0.10 & 0.05 & 0.06 & 0.20 & 0.84 & 0.17 \\
\hline Sterane $\mathrm{C}_{29} /\left(\mathrm{C}_{27}+\mathrm{C}_{28}+\mathrm{C}_{29}\right)$ & 0.74 & 0.68 & 0.63 & 0.64 & 0.58 & 0.42 & 0.45 & 0.27 \\
\hline Sterane $C_{27} /\left(C_{27}+C_{29}\right)$ & 0.09 & 0.24 & 0.22 & 0.08 & 0.25 & 0.41 & 0.44 & 0.28 \\
\hline Homohopane index & 0.01 & 0.04 & 0.01 & 0.01 & 0.01 & 0.24 & 0.04 & 0.05 \\
\hline Moretane/ $\mathrm{C}_{30}$ hopane & 0.87 & 0.71 & 0.50 & 0.68 & 0.76 & 0.32 & 0.37 & 0.87 \\
\hline Hopane/sterane & 66.7 & 43.7 & 26.8 & 186 & 64.9 & 1.55 & 15.7 & 6.03 \\
\hline Sterane/hopane & 0.02 & 0.02 & 0.04 & 0.01 & 0.02 & 0.65 & 0.06 & 0.17 \\
\hline Hopane $(\mu \mathrm{g} / \mathrm{g}$ TOC) & 9.61 & 4.45 & 36.3 & 14.2 & 23.3 & 0.22 & 9.80 & 2.38 \\
\hline Oleanane ( $\mu \mathrm{g} / \mathrm{g}$ TOC) & 0.15 & 0.15 & 0.82 & 0.08 & 0.20 & 0.01 & 1.56 & 0.06 \\
\hline
\end{tabular}

*Weathered sample.

$R_{o}=$ vitrinite reflectance.

$P I=$ production index: $S_{1} /\left(S_{1}+S_{2}\right)$.

$\operatorname{Pr} / \mathrm{Ph}=$ pristane/phytane.

$C P I=$ carbon preference index.

$C P I=1 / 2\left[\left(C_{25}+C_{27}+C_{29}+C_{31}+C_{33}\right) /\left(C_{24}+C_{26}+C_{28}+C_{30}+C_{32}\right)+\left(C_{25}+C_{27}+C_{29}+C_{31}+C_{33}\right) /\left(C_{26}+C_{28}+C_{30}+C_{32}+C_{34}\right)\right]$

Total n-alkanes $=\operatorname{sum}\left(C_{16}+C_{17}+\cdots+C_{38}+C_{39}\right)$.

$T s /(T s+T m)=22,29,30$-Trisnorhopane/(22,29,30-Trisnorhopane + 22,29,30-Trisnorneohopane $)$.

Homohopane index $=$ hopane $C_{35}$ /hopane $\left(C_{31}-C_{35}\right)$.

perature was programmed from 40 to $300^{\circ} \mathrm{C}$ (held for 12 min) at $15^{\circ} \mathrm{C} \mathrm{min}^{-1}$. The interface was set at $280^{\circ} \mathrm{C}$.

\section{Carbon isotopes of the organic matter (OM)}

Pulverized samples and oxidized copper were placed in quartz tubes, taken to vacuum conditions, and then heated at $900^{\circ} \mathrm{C}$ for 2 hours. The stable carbon isotope ratios of the $\mathrm{CO}_{2}$ extracted from these samples were determined by Geoscience Laboratory Inc. (Chikyu Kagaku Kenkyusho).

\section{RESULTS}

Total organic carbon (TOC), total sulfur (TS), C/N ratios, and $\mathrm{C} / \mathrm{S}$ ratios

Total organic carbon contents of the upper Eocene coals and coaly shales range from $2.08 \mathrm{wt} \%$ to $57.6 \mathrm{wt} \%$ (Table 1a; Fig. 3a). Sulfur contents are slightly elevated in Phase-I coaly shale A2-52 and in Phase-II coal A1-92, at $1.14 \mathrm{wt} \%$ and $3.95 \mathrm{wt} \%$, respectively (Fig. 3b), but the remainder of the samples are sulfur-poor $(<0.47 \mathrm{wt} \%)$. 


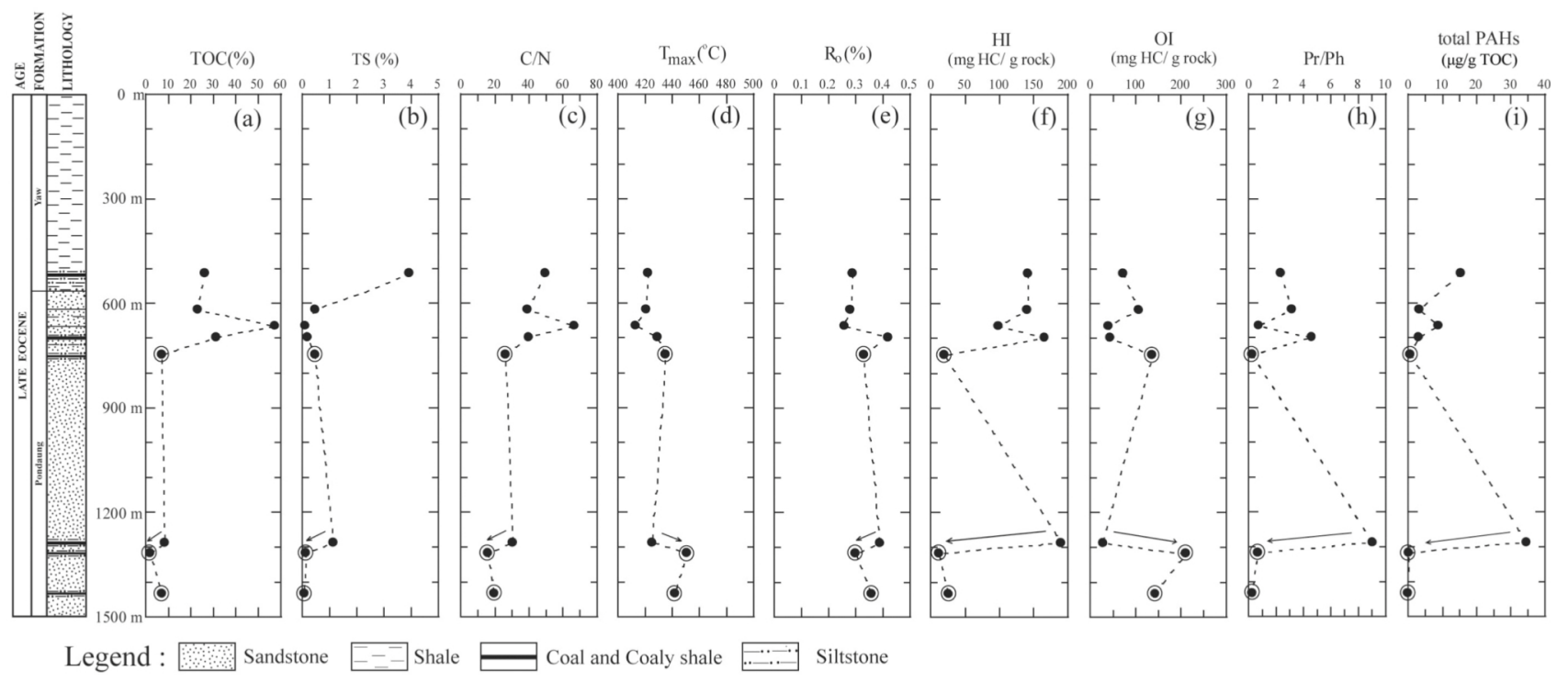

Fig. 3. Total organic carbon (TOC) and total sulfur (TS) contents, total organic carbon/total nitrogen ratio $(C / N)$, $T_{\text {max }}$, vitrinite reflectance $\left(R_{o}\right)$, and differing distributions of hydrogen index $(H I)$, oxygen index $(O I)$, pristanelphytane $(P r / P h)$, and total PAHs for the Upper Eocene coals and coaly shales. Circled data points indicate weathered samples. Arrows show slight changes in elemental, $T_{\max }$ and vitrinite reflectance data and significant changes in HI, OI, Pr/Ph and total PAHs between weathered and unweathered samples in the same horizon.

All $\mathrm{C} / \mathrm{N}$ ratios are high, with a range from 16.0 to 66.8 (Fig. 3c), as are C/S ratios (range 6.6-612) (Table 1a).

\section{Microscopic investigation and vitrinite reflectance}

During microscopic investigation, irregular microfissures and dull oxidation rims were observed on the edges of oxidized vitrinite particles (Figs. $2 \mathrm{~d}$ and $2 \mathrm{e}$ ) in three coaly shales (A2-54, A2-52A, A1-120). Vitrinite reflectance $\left(R_{o}\right)$ values are relatively uniform, ranging from 0.26 to $0.42 \%$ (Fig. 3e; Table 1 a).

\section{Rock-Eval pyrolysis}

Free hydrocarbon contents $\left(\mathrm{S}_{1}\right)$, the amount of kerogen-bonded hydrocarbon yield $\left(\mathrm{S}_{2}\right)$, and the carbon dioxide of organic origin $\left(\mathrm{S}_{3}\right)$ expelled during pyrolysis are listed in Table 1a. All samples exhibited elevated pyrolysis $\mathrm{S}_{2}$ yields, with a range of $0.25-57.3 \mathrm{mg} \mathrm{HC} / \mathrm{g}$. The Phase-II coals are characterized by moderate Hydrogen Index (HI) values of 100-166 mg HC/g TOC, whereas the Phase-I coaly shales have more variable HI of $12-$ $191 \mathrm{mg} \mathrm{HC} / \mathrm{g}$ TOC (Fig. 3f; Table 1a). Oxygen Index (OI) values are lower in unweathered samples and higher in weathered samples (Fig. 3g; Table 1a). $T_{\max }$ (temperature at maximum evolution of $\mathrm{S}_{2}$ hydrocarbons) values range between $413^{\circ} \mathrm{C}$ and $451^{\circ} \mathrm{C}$ (Fig. 3d; Table 1a), and Production Index (PI) values vary from 0.01 to 0.11 (Table 1a).

The modified van Krevelen diagram (HI-OI diagram) shows a mixture of Type II and Type III kerogens in the OM of fresh samples (Fig. 6).

\section{n-Alkanes, biomarkers and PAHs}

Biomarkers are useful as source indicators to distinguish between marine and continental land plants, and for reconstruction of paleo-environments (Peters and Moldowan, 1993; Meyers, 1997). Biomarker data for all samples are listed in Table 1b.

(a) $n$-Alkanes and acyclic isoprenoids ( $\mathrm{Pr} / \mathrm{Ph}, \mathrm{Pr} / \mathrm{n}-\mathrm{C}_{17}$, $P h / n-C_{18}$ ) The distributions of $n$-alkanes in the upper Eocene coals and coaly shales from the Yaw and Pondaung Formations were identified in the range $n-\mathrm{C}_{17}-n-\mathrm{C}_{33}(\mathrm{Fig}$. $4 a)$. The $n$-alkanes have been classified as short- $\left(<n-\mathrm{C}_{20}\right)$, mid- $\left(n-\mathrm{C}_{21}-n-\mathrm{C}_{26}\right)$, and long chain $\left(n-\mathrm{C}_{27}-n-\mathrm{C}_{33}\right)$ homologues. Mid-chain $\left(n-\mathrm{C}_{21}-n-\mathrm{C}_{25}\right) n$-alkanes with a maximum intensity at $n-\mathrm{C}_{22}$ are dominant in Phase-II sample A1-92, while most other samples show predominance in both mid-chain $\left(n-\mathrm{C}_{21}-n-\mathrm{C}_{25}\right)$ and long-chain $\left(n-\mathrm{C}_{27}-n\right.$ $\mathrm{C}_{32}$ ) $n$-alkanes (Fig. 4a). Carbon preference index (CPI) values were calculated based on the formula $1 /$ $2\left[\left(\mathrm{C}_{25}+\mathrm{C}_{27}+\mathrm{C}_{29}+\mathrm{C}_{31}+\mathrm{C}_{33}\right) /\left(\mathrm{C}_{24}+\mathrm{C}_{26}+\mathrm{C}_{28}+\mathrm{C}_{30}+\mathrm{C}_{32}\right)+\right.$ $\left.\left(\mathrm{C}_{25}+\mathrm{C}_{27}+\mathrm{C}_{29}+\mathrm{C}_{31}+\mathrm{C}_{33}\right) /\left(\mathrm{C}_{26}+\mathrm{C}_{28}+\mathrm{C}_{30}+\mathrm{C}_{32}+\mathrm{C}_{34}\right)\right]$ (Peters and Moldowan, 1993). All CPI values are greater than 1, with a range of 1.16-2.25 (Table 1b). With one exception, the samples show a range of quite low to high concentrations of pristane $(\mathrm{Pr})$ and phytane $(\mathrm{Ph})$, from 0.002 17.9 and $0.01-1.96 \mu \mathrm{g} / \mathrm{g}$ TOC, respectively. One coaly 
(a)
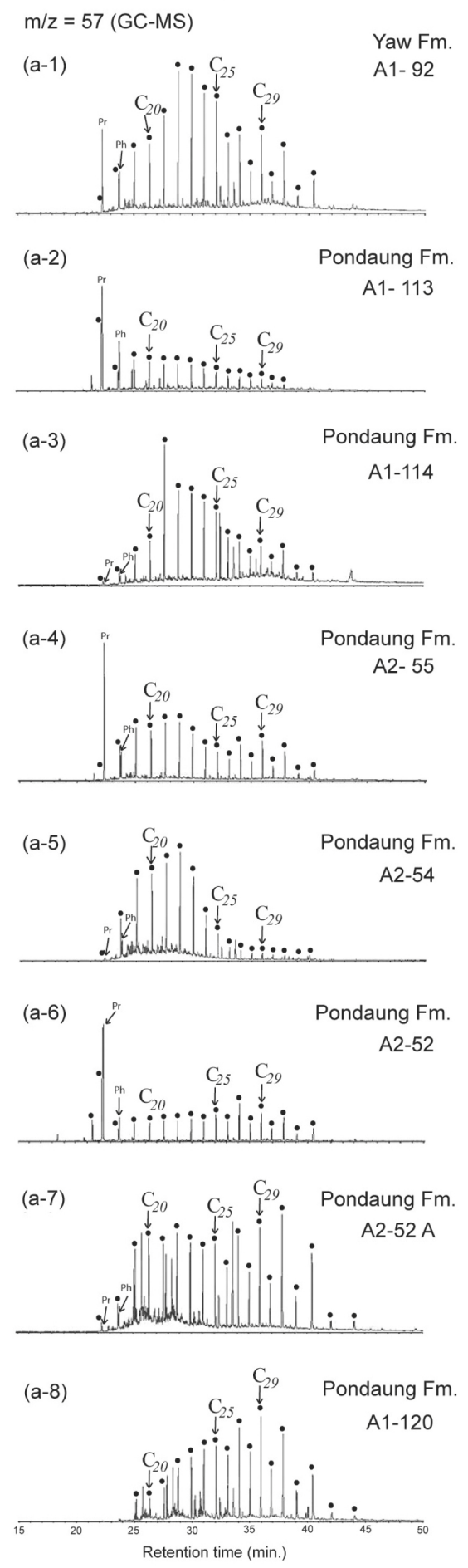

(b)
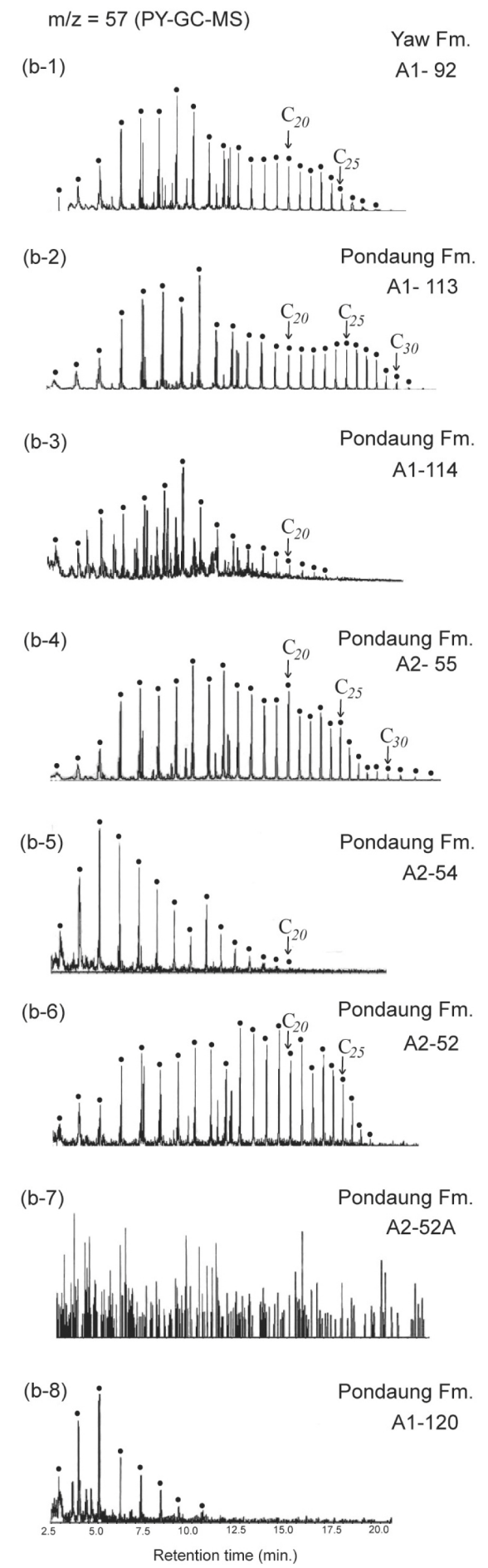

Fig. 4. Ion chromatograms from (a) gas chromatography and mass spectrometry (GC-MS) and (b) pyrolysis-GC-MS of Upper Eocene coals and coaly shales, $C M B$. 


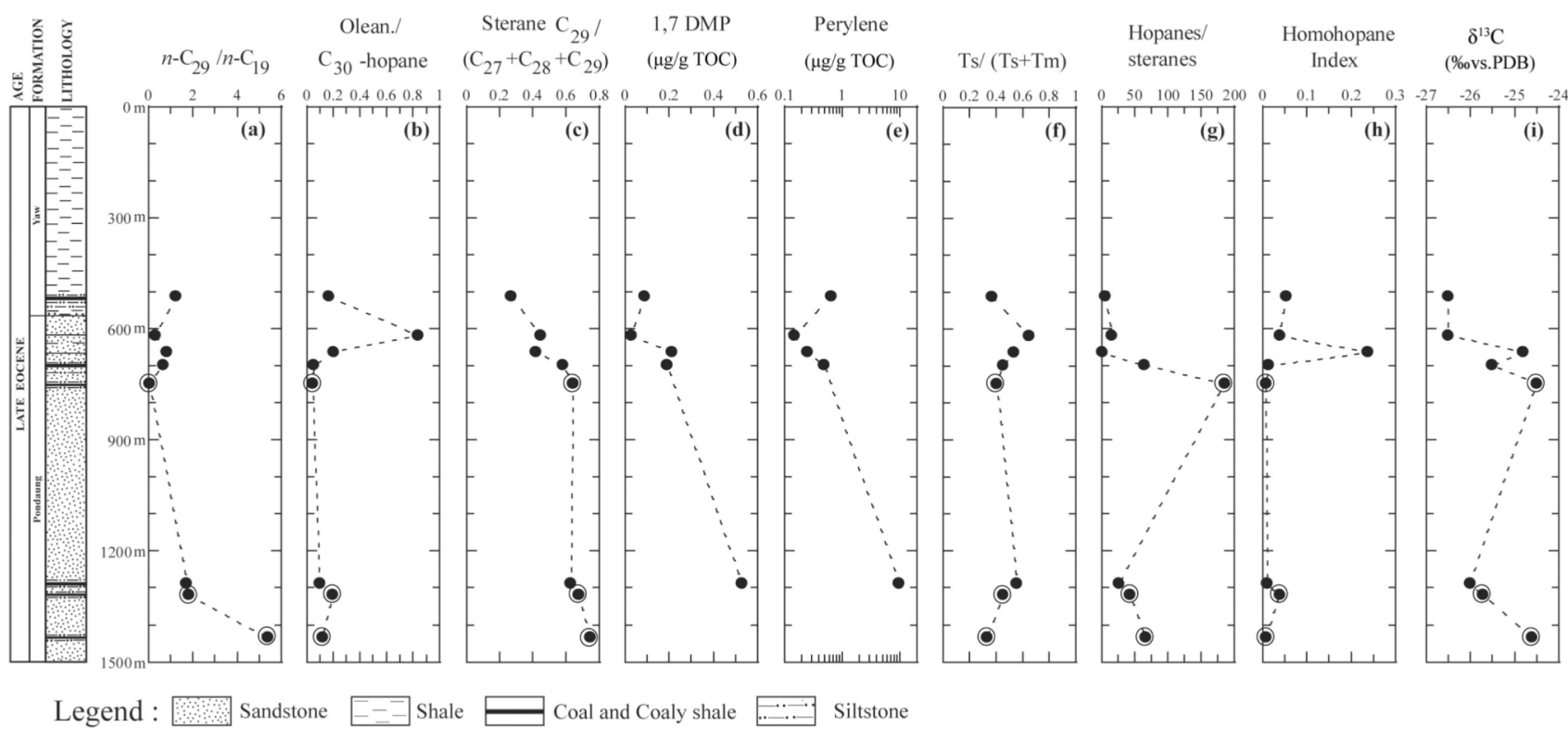

Fig. 5. Biomarker concentrations and ratios of the Upper Eocene coals and coaly shales in the CMB. Circled data points indicate weathered samples.

shale sample (A2-52) has significantly higher values of $\operatorname{Pr}(17.9 \mu \mathrm{g} / \mathrm{g}$ TOC $)$ and $\mathrm{Ph}(1.96 \mu \mathrm{g} / \mathrm{g}$ TOC $)$. $\mathrm{Pr} / \mathrm{Ph}$ ratios thus range from 0.23 to 9.09 (Fig. 3h; Table 1b). The Pr/ $n-\mathrm{C}_{17}$ values are high (1.87-9.86) and $\mathrm{Ph} / n-\mathrm{C}_{18}$ values are relatively low $(0.48-2.96)$ in all samples.

(b) Hopanes (Pentacyclic triterpanes) Pentacyclic triterpanes $(\mathrm{m} / \mathrm{z} 191)$ originating from bacteria/land plants are significantly enriched. In five samples Tm $(17 \alpha(\mathrm{H})$ $22,29,30$-trisnohopane) is dominant over Ts $(18 \alpha(\mathrm{H})$ 22,29,30-trisnorneohopane), whereas in two Phase-II samples (A1-113, A1-114) and one Phase-I sample (A2-52), Ts predominates over $\mathrm{Tm}$. Oleanane/ $\mathrm{C}_{30}$ hopane ratios are higher in the Phase-II coals than in Phase-I coaly shales (Fig. 5b; Table 1b). Oleanane is highly enriched in PhaseII coal A1-113, at $1.56 \mu \mathrm{g} / \mathrm{g}$ TOC (Table $1 \mathrm{~b}$ ). In terms of the homohopanes, $\mathrm{C}_{30} 17 \beta, 21 \alpha(\mathrm{H})$-hopane is most abundant in most samples. One exception is Phase-II coal A192, which has a high $\mathrm{C}_{29} 17 \beta, 21 \alpha(\mathrm{H})$-hopane content. Contents of $\mathrm{C}_{31}-\mathrm{C}_{33}$ homologues are high in all samples, whereas values of the $\mathrm{C}_{35}$ homohopane index are very low $(<0.05)$, except for a value of 0.24 in one Phase-II coal (Fig. 5h; Table 1b). Hopane/sterane ratios are generally higher in the coaly shales than in the coals (Fig. $5 \mathrm{~g}$; Table $1 b)$. Values of $\mathrm{C}_{31} 22 \mathrm{~S} /(22 \mathrm{~S}+22 \mathrm{R}), \mathrm{C}_{32} 22 \mathrm{~S} /$ $(22 \mathrm{~S}+22 \mathrm{R})$, moretane $/ \mathrm{C}_{30}$ hopane, $\mathrm{Ts} / \mathrm{Tm}$ and $\mathrm{Ts} /(\mathrm{Ts}+\mathrm{Tm})$ range between 0.23 and $0.56,0.54$ and $0.86,0.32$ and 0.87 , 0.50 and 1.86 , and 0.33 and 0.65 , respectively (Table $1 \mathrm{~b}$ ). (c) Steranes Regular steranes are dominant. The $\mathrm{C}_{28}$ sterane concentration is significantly greater $(63 \%)$ than $\mathrm{C}_{27}$ sterane and $\mathrm{C}_{29}$ sterane in Phase-II coal A1-92, while the other coals show predominance of $\mathrm{C}_{29}$ steranes (42$74 \%)$. Most Phase-I coaly shales are enriched in $\mathrm{C}_{29}$ steranes (63-74\%). Regular sterane $\mathrm{C}_{29}-20 \mathrm{~S} /(20 \mathrm{~S}+20 \mathrm{R})$ values range from 0.03 to 0.37 overall, and sterane $\mathrm{C}_{29} /$ $\left(\mathrm{C}_{27}+\mathrm{C}_{28}+\mathrm{C}_{29}\right)$ ratios are uniformly greater $(0.63-0.74)$ in the Phase-I coaly shales than in the Phase-II coals (0.27-0.58) (Fig. 5c; Table 1b).

(d) Polycyclic aromatic hydrocarbons (PAHs) Aromatic compounds comprising combustion/diagenesis-derived PAHs (Table 2) and their alkylated hydrocarbons are relatively abundant in unweathered samples. Various unsubstituted PAHs were detected, including 2-6 ring compounds such as Cad, Phe, An, Py, Ret, Fla, BaAn, Chry+Tpn, Bflas, BePy, BaPy, Pery, InPy, and BghiP. Total PAH concentration is greatest in Phase-I coaly shale A2-52 (Fig. 3i).

Concentrations of two to five-ring PAHs are relatively high in unweathered samples. Six-ring PAHs such as InPy and BghiP were present at low levels in Phase-II coal A1114 , but were not detected in other coal or in phase-I coaly shale A2-54 (Table 2). Methyl derivatives such as methylphenanthrenes (3-MP, 2-MP, (9+4)-MP, 1-MP) and dimethylphenanthrenes (DMPs) were detected in the coals and the unweathered coaly shale A2-52. 1,7 DMP is more abundant $(0.53 \mu \mathrm{g} / \mathrm{g}$ TOC $)$ in A2-52 than in the coals $(0.03-0.21 \mu \mathrm{g} / \mathrm{g}$ TOC), but was not detected in the other three coaly shales (Table 2). The same pattern is seen for perylene, which is abundant in A2-52 $(9.86 \mu \mathrm{g} / \mathrm{g}$ TOC), present at lower levels in all coals $(0.15-0.66 \mu \mathrm{g} / \mathrm{g}$ TOC), but was not detected in the remaining coaly shales (Fig. 
Table 2. Concentrations of polycyclic aromatic hydrocarbons $(\mu \mathrm{g} / \mathrm{g}$ TOC) in the Upper Eocene coals and coaly shales of the Central Myanmar Basin, Myanmar. Abbreviations are: BaAn, benzo[a]anthracene; Chry $+T p n$, chrysene/triphenylene; Bflas, benzofluoranthenes; BePy, benzo[e]pyrene; BaPy, benzo[a]pyrene; Pery, perylene, MP, methyl phenanthrenes; nd, not detected.

\begin{tabular}{|c|c|c|c|c|c|c|c|c|}
\hline \multirow{2}{*}{$\begin{array}{l}\text { Group } \\
\text { Sample }\end{array}$} & \multicolumn{4}{|c|}{ Phase-I coaly shales } & \multicolumn{4}{|c|}{ Phase-II coals } \\
\hline & $* \mathrm{~A} 1-120$ & $* A 2-52 \mathrm{~A}$ & A2-52 & $* A 2-54$ & A2-55 & A1-114 & A1-113 & A1-92 \\
\hline Cadalene (Cad) $(\mu \mathrm{g} / \mathrm{g}$ TOC $)$ & nd & nd & 9.12 & nd & 0.32 & nd & 0.02 & 3.10 \\
\hline Anthracene (A) $(\mu \mathrm{g} / \mathrm{g}$ TOC) & nd & nd & 0.24 & nd & 0.05 & nd & nd & 1.97 \\
\hline Phenanthrene $(\mathrm{P})(\mu \mathrm{g} / \mathrm{g}$ TOC $)$ & nd & nd & 0.16 & nd & 0.08 & 0.42 & 0.03 & 0.64 \\
\hline Fluoranthene (Fla) $(\mu \mathrm{g} / \mathrm{g}$ TOC) & nd & nd & 0.20 & 0.04 & 0.16 & 0.81 & 0.11 & 1.05 \\
\hline Pyrene (Py) ( $\mu \mathrm{g} / \mathrm{g}$ TOC) & nd & nd & 0.93 & 0.01 & 0.37 & 1.24 & 0.17 & 0.37 \\
\hline Retene (Ret) $(\mu \mathrm{g} / \mathrm{g}$ TOC) & 0.01 & 0.05 & 0.03 & 0.12 & 0.16 & nd & 0.02 & nd \\
\hline $\operatorname{BaAn}(\mu \mathrm{g} / \mathrm{g}$ TOC $)$ & nd & nd & 1.76 & 0.04 & 0.25 & 0.40 & 0.48 & 0.17 \\
\hline Chry+Tpn $(\mu \mathrm{g} / \mathrm{g}$ TOC $)$ & nd & nd & 0.84 & 0.01 & 0.32 & 0.74 & 0.17 & 2.25 \\
\hline Bflas $(\mu \mathrm{g} / \mathrm{g}$ TOC) & nd & nd & 1.81 & 0.05 & 0.11 & 0.85 & 0.98 & 0.49 \\
\hline $\mathrm{BePy}(\mu \mathrm{g} / \mathrm{g}$ TOC) & nd & nd & 5.50 & 0.08 & 0.10 & 1.16 & 0.91 & 0.86 \\
\hline $\mathrm{BaPy}(\mu \mathrm{g} / \mathrm{g}$ TOC) & nd & nd & 1.85 & 0.02 & 0.04 & 0.29 & nd & 0.56 \\
\hline Perylene ( $\mu \mathrm{g} / \mathrm{g}$ TOC) & nd & nd & 9.86 & nd & 0.49 & 0.26 & 0.15 & 0.66 \\
\hline InPy $(\mu \mathrm{g} / \mathrm{g}$ TOC) & nd & nd & nd & 0.06 & nd & 0.13 & nd & nd \\
\hline $\operatorname{BghiP}(\mu \mathrm{g} / \mathrm{g}$ TOC $)$ & nd & nd & nd & 0.10 & nd & 0.14 & nd & nd \\
\hline Cor $(\mu \mathrm{g} / \mathrm{g}$ TOC $)$ & nd & nd & nd & nd & nd & nd & nd & nd \\
\hline 1,7 DMP $(\mu \mathrm{g} / \mathrm{g}$ TOC $)$ & nd & nd & 0.53 & nd & 0.19 & 0.21 & 0.03 & 0.09 \\
\hline 3-MP ( $\mu \mathrm{g} / \mathrm{g}$ TOC) & nd & nd & 0.32 & nd & 0.06 & 0.29 & 0.02 & 0.26 \\
\hline 2-MP $(\mu \mathrm{g} / \mathrm{g}$ TOC $)$ & nd & nd & 0.41 & nd & 0.09 & 0.37 & 0.07 & 0.70 \\
\hline 9-MP $(\mu \mathrm{g} / \mathrm{g}$ TOC $)$ & nd & nd & 0.46 & nd & 0.13 & 0.93 & 0.03 & 1.51 \\
\hline 1-MP $(\mu \mathrm{g} / \mathrm{g}$ TOC $)$ & nd & nd & 0.75 & nd & 0.14 & 0.60 & 0.05 & 0.87 \\
\hline $\mathrm{Fla} /(\mathrm{Fla}+\mathrm{Py})$ & nd & nd & 0.18 & 0.73 & 0.31 & 0.40 & 0.38 & 0.74 \\
\hline Non-alkylated PAHs ${ }^{\mathrm{a}}(\mu \mathrm{g} / \mathrm{g}$ TOC $)$ & nd & nd & 13.3 & 0.42 & 1.49 & 6.17 & 2.83 & 8.37 \\
\hline Total PAHs ${ }^{\mathrm{b}}(\mu \mathrm{g} / \mathrm{g}$ TOC $)$ & 0.01 & 0.05 & 34.8 & 0.54 & 3.07 & 8.83 & 3.22 & 15.6 \\
\hline
\end{tabular}

${ }^{a}$ Non-alkylated PAHs $=(A+P+F l a+P y+B a A n+C h r y+T p n+B f l a s+B e P y+B a P y+I n P y+B g h i P+C o r)$.

${ }^{b}$ Total PAHs $=(C a d+A+P+F l a+P y+R e t+B a A n+C h r y+T p n+B f l a s+B e P y+B a P y+P e r y+I n P y+B g h i P+C o r+1,7 D M P+3 M P+2 M P+9 M P+1 M P)$.

*Weathered sample.

5e; Table 2).

(e) Sesquiterpenoids, diterpenoids and triterpenoids with non-hopanoid skeletons Sesquiterpenoid-derived cadalene $\left(\mathrm{C}_{15} \mathrm{H}_{18}\right)$ is abundant in coaly shale $\mathrm{A} 2-52$ and coal A1-92, present in coals A1-113, A2-55, and not detected in the remaining samples (Table 2). Aromatic diterpenoids such as retene $(\mathrm{m} / \mathrm{z} 219)$ were detected in trace amounts in most samples (Table 2).

(f) Carbon isotopes of the OM Phase-I coaly shales have $\delta^{13} \mathrm{C}$ values ranging from -24.5 to $-26 \%$, and the PhaseII coals vary from -24.8 to $-26.5 \%$ (Fig. 5 i; Table 1 a).

\section{Discussion}

\section{Moderate weathering processes}

The compositions of three outcropping coaly shale samples (A2-54, A2-52A, A1-120) have been moderately altered by oxidation and weathering in the humid tropi- cal climate of central Myanmar, which has a mean annual rainfall of $1000 \mathrm{~mm}$, and an average temperature of more than $27^{\circ} \mathrm{C}$. Microscope investigation identified many thin, irregular micro-fissures and dark oxidation rims on the edges of oxidized vitrinite particles (Figs. 2d and 2e). The weathered samples are brownish-black and partly brown in color, and are characteristically more friable than the unweathered coals. This color feature also indicates progressive alteration of coal to soil (Copard $e t$ al., 2002). Petsch et al. (2000) showed that if carbonaceous shales are permeable, this condition can favour oxidation of the surface of organic matter, which is subsequently degraded during weathering. This feature is supported by the pair of fresh (A2-52) and weathered (A2-52A) coaly shales collected from the same seam in the Pondaung Formation. These show obvious loss of TOC (from 8.6 to $2.1 \mathrm{wt} \%$, respectively) due to weathering. Increased permeability in the coaly shales thus favours 
chemical weathering along the micro-fissures.

$T_{\max }$ has been used as a parameter to determine not only maturation, but also the extent of oxidation (Copard et al., 2002). The $T_{\max }$ values of $451^{\circ} \mathrm{C}$ in the weathered coaly shale (A2-52A) are clearly greater than the $425^{\circ} \mathrm{C}$ determined for the fresh coaly shale (A2-52) (Table 1a), even though $R_{o}$ of these samples are similar $(0.30$ and $0.39 \%$, respectively), showing immaturity. The increased $T_{\max }$ may be caused by a decrease in hydrocarbons weakly bonded to kerogen. The three weathered coaly shales analyzed here are characterized by high $T_{\max }$ values (435$\left.451^{\circ} \mathrm{C}\right)$ related to their very high OI values $(137-212 \mathrm{mg}$ $\mathrm{CO}_{2}$ /g TOC; Fig. 3g), low $\mathrm{Pr} / \mathrm{Ph}$ ratios (0.23-0.69; Fig. $3 \mathrm{~h})$ and low HI values (12-26 mg HC/g TOC; Table 1a and Fig. 3f). Copard et al. (2000) considered that anomalously high $T_{\max }\left(500-575^{\circ} \mathrm{C}\right)$ and OI (50-80 $\mathrm{mg} \mathrm{CO} / \mathrm{g}$ TOC) values in immature or slightly mature samples showed the effects of oxidation of organic matter at high temperature. The low $\mathrm{Pr} / \mathrm{Ph}$ ratios may be produced by decreased concentrations due to the effect of water washing, and the loss of light molecular weight hydrocarbons which are partly soluble in water (e.g., Martínez and Escobar, 1995).

The Py-GC-MS compositions of the weathered samples show marked decrease in long chain $n$-alkanes $(>n$ $\mathrm{C}_{20}$ ) bonded to kerogen (Fig. 4b). This suggests that bonded hydrocarbons may be lost due to change in $\mathrm{pH}$ to acidic conditions, because acid hydrolysis could decrease the bonded long fatty acids (e.g., Martínez and Escobar, 1995). The PAHs in the weathered samples (mostly 3- to 5-ring compounds) are either decreased significantly in concentration or are totally lost (Table 2). Pery, Phe, BaPy and BePy are unstable during oxidation (e.g., Kawka and Simoneit, 1990), and all have been reduced or lost in these samples (Table 2). Methyl derivatives of PAHs such as MPs (Table 2) have also been lost from all three weathered samples.

Nevertheless, the fresh and weathered sample pair (A2-52 and A2-52A) shows no notable differences in relative relationship of free $n$-alkane content, biomarkers such as distributions of steranes and triterpanes, or kerogen $\delta^{13} \mathrm{C}$ isotopic ratio (Figs. $4 \mathrm{a}$ and $5 \mathrm{i}$ ), despite the moderate weathering. Therefore, these data could be used as representative markers to identify the origin of organic matter.

\section{Thermal maturity and type of organic matter}

The Upper Eocene sediments have $R_{o}$ values ranging from 0.26 to $0.42 \%$ (Table 1a), indicating immature OM. $T_{\max }$ values of 413 to $429^{\circ} \mathrm{C}$ for the fresh samples also suggests immaturity, in agreement with the immature $R_{o}$ values $(<0.5 \%)$. Peters (1986) stated that $T_{\max }$ values of less than $435^{\circ} \mathrm{C}$ indicated immature $\mathrm{OM}$. The sterane $\mathrm{C}_{29}$ $20 \mathrm{~S} /(20 \mathrm{~S}+20 \mathrm{R})$ ratio is used as a maturity indicator; values here also indicate thermally immature $\mathrm{OM}(0.03-0.37$;

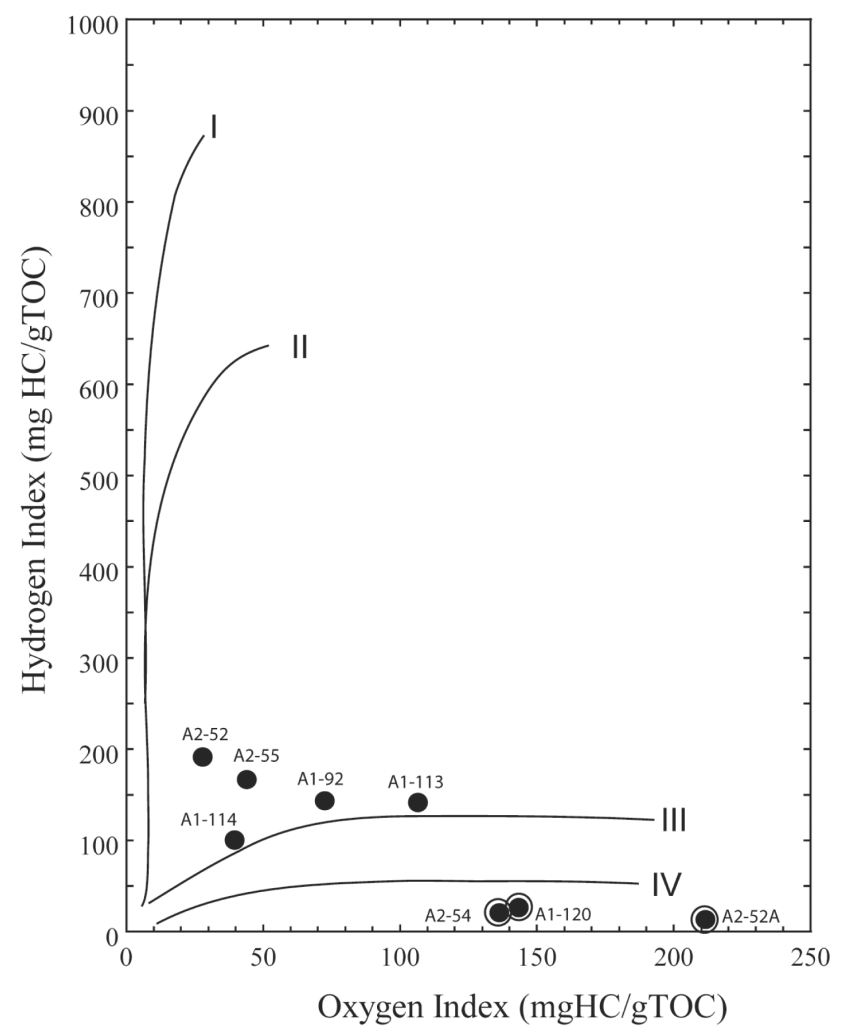

Fig. 6. Modified van Krevelen diagram (HI-OI diagram) showing mixed Type II and Type III kerogens in the Upper Eocene coals and coaly shales, indicating that most are gas-prone. Circled data points indicate weathered samples.

Table 1b). High Carbon Preference Index (CPI) values of more than 1 (1.2-2.3; Table 1b) further indicate immaturity. Moretane $/ \mathrm{C}_{30}$ hopane ratios (Table $1 \mathrm{~b}$ ) in the upper Eocene samples vary from 0.32 to 0.87 , within the range of $0.15-0.8$ that indicates immaturity (Peters and Moldowan, 1993).

The HI-OI diagram shows that the unweathered coaly shale is characterized by a mixture of Type II and Type III kerogens (Fig. 6). Hydrocarbon generation potential for these coals and coaly shale may be reasonably good for gas, based on the value of nearly $200 \mathrm{mg} \mathrm{HC} / \mathrm{g}$ TOC (HI: Fig. 3f). Generally, OM is categorized as Type II (oil prone) on the basis of HI values with $300-600 \mathrm{mg}$ HC/g TOC, Type III (gas prone) with HI of $200-300 \mathrm{mg}$ $\mathrm{HC} / \mathrm{g}$ TOC, and Type IV (inertinite) when $\mathrm{HI}$ is $<50 \mathrm{mg}$ HC/g TOC (Peters, 1986).

\section{Origins of organic matter}

Change in sedimentary facies from the coaly shale layers (Phase-I) to the coal layers (Phase-II) seems to be accompanied by change in the origin of the organic matter. The coals (Phase-II) have $\mathrm{C} / \mathrm{N}$ ratios greater than 30 (39.3-66.8), indicating vascular plant sources (Meyers 
and Ishiwatari, 1993; Meyers, 1994). $\mathrm{C} / \mathrm{N}$ ratios of the coaly shales (Phase-I) range from 16.0 to 30.6, and are clearly lower than those of the vascular plant-derived coals.

In general, short chain $n$-alkanes $\left(n-\mathrm{C}_{12}-n-\mathrm{C}_{19}\right)$ are derived from plankton (Meyers, 1997), algae and microorganisms (Cranwell, 1977; Cranwell et al., 1987), whereas long chain $n$-alkanes $\left(n-\mathrm{C}_{20}-n-\mathrm{C}_{35}\right)$ are derived from vascular plant waxes (Tissot and Welte, 1984). Dominance in mid-chain $n$-alkanes $\left(n-\mathrm{C}_{20}-n-\mathrm{C}_{26}\right)$ can reflect an origin from bacteria and aquatic plants (Davis, 1968; Ficken et al., 2000; Nott et al., 2000). Submerged and floating aquatic plants commonly show maxima at $n$-alkanes $\mathrm{C}_{21}, \mathrm{C}_{23}$, and $\mathrm{C}_{25}$ (De Souza et al., 2011). In our present study, the relative abundance of $n-\mathrm{C}_{20}-n-\mathrm{C}_{33}$ alkanes and maxima at $n-\mathrm{C}_{21}$ in Phase-II coals A1-114 and $\mathrm{A} 2-55$ and at $n-\mathrm{C}_{22}$ in A1-92 suggest that the OM mainly originated from vascular plants, along with a secondary contribution from aquatic plants and/or bacteria. In contrast, the Phase-I coaly shales clearly exhibit predominance of odd-over-even carbon numbers in waxderived long-chain $n$-alkanes $\left(n-\mathrm{C}_{27}-n-\mathrm{C}_{33}\right)$. The average CPI value of 1.9 of the Phase-I coaly shales is greater than the 1.7 average of the Phase-II coals, suggesting a slightly more abundant contribution of vascular plant waxes in the former relative to the latter. High $\mathrm{Pr} / \mathrm{Ph}$ ratios in the unweathered coaly shales (9.1 in A2-52; Table 1b) can indicate not only inputs of vascular plant waxes, but also an oxic depositional environment (e.g., Fabiańska et al., 2013). The sterane $\mathrm{C}_{27} /\left(\mathrm{C}_{27}+\mathrm{C}_{29}\right)$ ratio is higher in Phase-II coals than in phase II coaly shales, suggesting additional planktonic inputs (Table $1 \mathrm{~b}$ ).

Retene has been identified as a biomarker for many vascular plants such as gymnosperms, especially resinous conifers (Noble et al., 1986; Simoneit et al., 1986; Otto et al., 1997, 2003; Otto and Simoneit, 2001; PiedadSánchez et al., 2004), whereas triterpenoids are markers of angiosperms (Moldowan et al., 1994; Nakamura et al., 2010). Presence of retene and related compounds in trace concentration in the Phase-II coals can be attributed to a small contribution of gymnosperms to their sedimentary OM. Retene can be transformed to 1,7-DMP (pimanthrene) (Simoneit et al., 1986; Armstroff et al., 2006), which itself originates mainly from pine resin abietic acid (Wakeham et al., 1980; Radke et al., 1982; Simoneit et al., 1986; Budzinski et al., 1997). The low abundances of 1,7-DMP (pimanthrene) in the Phase-II coals (0.03-0.21 $\mu \mathrm{g} / \mathrm{g}$ TOC; Table 2) also suggest limited contribution from resinous vascular plants, especially conifers (e.g., Del Rio et al., 1992). In contrast, the higher 1,7-DMP content in coaly shale A2-52 (0.53 $\mu \mathrm{g} / \mathrm{g}$ TOC) suggests a greater contribution of resinous materials in Phase-I. Higher oleanane/ $\mathrm{C}_{30}$ hopane in the Phase-II coals (Fig. 5b) indicates an abundant contribution of angiosperm vegetation (Philp and Gilbert, 1986; Peters and Moldowan, 1993; Moldowan et al., 1994). These values do not show absolute contributions, but can indicate relative proportions. Therefore, these results indicate possibilities in Phase-II (coals) after Phase-I (coaly shales) such as an increase of angiosperm and/or a decrease of gymnosperm in absolute plant-production.

The upper Eocene CMB samples studied here are thus characterized by mixed inputs of angiosperm and gymnosperm vegetation. The Phase-I coaly shales reflect mixed inputs of abundant resinous conifers (i.e., gymnosperms) and lesser angiosperm plants, whereas the paleovegetation supplying the Phase-II coals was mainly dominated by angiosperms, with a minor gymnosperm component. Cadalene $\left(\mathrm{C}_{15} \mathrm{H}_{28}\right)$ is one of the precursors of the cyclic sesquiterpenoidal hydrocarbons in vascular plant resins (Simoneit et al., 1986; Otto et al., 1997; Killops and Killops, 2005) and can be a product of diagenetic transformation of sesquiterpenoid biomarkers (Simoneit, 2005; cf., Stefanova et al., 2013). The relatively high concentrations of ses- and tri-terpenoid markers (e.g., cadalene and oleanane) in the Phase-II coals thus suggest that their OM mainly contains inputs of angiosperms, with a small contribution from resinous conifers. The Phase-I coaly shales are characterized by higher portions of diterpenoid compounds relative to triterpenoid compound markers, indicating more significant gymnospermdominated paleo-vegetation relative to angiosperms.

Lücke et al. (1999) showed that angiosperms had lighter $\delta^{13} \mathrm{C}$ values of about $-26 \%$ relative to gymnosperms (about-24\%o); Bechtel et al. (2003) also indicated that angiosperms average $\delta^{13} \mathrm{C}$ of $-25.5 \%$ to $-26.6 \%$, whereas gymnosperm vegetation averages between $-22.7 \%$ and $-25.1 \%$. Although $\delta^{13} \mathrm{C}$ of atmospheric $\mathrm{CO}_{2}$ can change during long geologic time spans, our samples were from a rather limited age range in the late Eocene, and the $\delta^{13} \mathrm{C}$ of atmospheric $\mathrm{CO}_{2}$ would have been roughly constant during the time interval concerned. The coaly shales have $\delta^{13} \mathrm{C}$ values ranging from $-24.5 \%$ to $-26.0 \%$ (Table 1, avg. $-25.2 \%$ ), suggesting influence of changes in peat-forming vegetation, with both gymnosperm and angiosperm contributions. On the other hand, the PhaseII coals have $\delta^{13} \mathrm{C}$ values ranging between $-24.8 \%$ and $-26.5 \%$ (Table 1a, avg. $-25.8 \%$ ), suggesting that the depositional environment was more influenced by angiosperm vegetation, with a minor gymnosperm contribution. The two uppermost coals $(-26.5 \%$ ) clearly show an abundant contribution of angiosperms, whereas the lowermost coaly shale (A1-120,-24.6\%o) reflects greater gymnosperm contribution.

Decreased $\mathrm{C}_{29}$ steranes originated from vascular plants (Huang and Meinschein, 1978, 1979) are observed in the Phase-II coals (Fig. 5c), and this also suggests an increase in algae/phytoplankton contribution relative to fungi/ter- 
restrial plants. Similarly, fungi-derived perylene decreases from the Phase-I coaly shales to the Phase-II coals (Fig. 5e). In addition, high hopane/sterane ratios (Fig. 5g; Table $1 \mathrm{~b}$ ) can be attributed to inputs of prokaryotic bacteria organisms (Peters et al., 2005; Mrkić et al., 2011). The wide range of hopane concentrations $(0.22-36.3 \mu \mathrm{g} / \mathrm{g}$ TOC, Table 1b) in the analyzed samples suggests extensive inputs of bacterial organic matter (e.g., Böcker et al., 2013) or preferential loss of hopanes by degradation. However, average hopane concentrations in the coaly shales (16.1 $\mu \mathrm{g} / \mathrm{g}$ TOC) are almost double those of the coals $(8.9 \mu \mathrm{g} / \mathrm{g}$ TOC), suggesting that bacterial activity may have decreased during the anoxic conditions (low $\mathrm{Pr} / \mathrm{Ph}$ ratios in Fig. 3h) of Phase-II coal deposition.

\section{Depositional environments}

The ratio of TOC to TS $(\mathrm{C} / \mathrm{S}$ ratio) in all upper Eocene samples is greater than 6 (Table 1), implying oxic marine or non-marine environments (marine $\mathrm{C} / \mathrm{S}<5$; Berner, 1984; Berner and Raiswell, 1984). Three coals (A1-113, A1-114, A2-55) are characterized by low sulphur contents (0.09-0.47 wt\%) and very high C/S ratios (49-612), implying that they were deposited in non-marine fresh water environments, such as those associated with fluvial-deltaic settings and coastal plains. The remaining coal (A1-92) has a high sulfur content (3.95 wt\%) and moderate $\mathrm{C} / \mathrm{S}$ ratio (6.6), suggesting deposition in an oxygen-poor environment inundated by seawater fluctuation during peat accumulation (e.g., near-shore and tidalinfluenced deltaic plain). The Phase-I coaly shale A2-52 also has a slightly elevated sulfur content (1.14 wt \%) and moderate $\mathrm{C} / \mathrm{S}$ ratio (7.5), and thus its OM may also have been deposited in a peat swamp in a fluvial-deltaic setting influenced by sea level fluctuations. Ts/Tm (22,29,30Trisnorhopane to 22,29,30-Trisnorneohopane) ratios in these upper Eocene sediments support the above interpretations. Ts/Tm ratios are known to be related to the characteristics of both maturity and contribution of marine organic matter (e.g., Seifert and Moldowan, 1978). Higher Ts/(Ts+Tm) ratios in the upper part of the PhaseII coals (Fig. 5f; Table 1b) suggest an increase in marine $\mathrm{OM}$ at that stage. These interpretations are consistent with the proposal of Chhibber (1934) that the Yaw Formation (upper Phase-II) was frequently influenced by marine waters, based on the presence of marine vertebrate fossils. According to Haq et al. (1987), cyclic sea level fluctuations of $+90 \mathrm{~m}$ increasing to $+150 \mathrm{~m}$ occurred in the period from 36.5 to 39.4 million years ago, consistent with the age of the upper Eocene Pondaung and Yaw Formations.

Low to high $\mathrm{Pr} / \mathrm{Ph}$ values of the fresh samples (Fig. $3 \mathrm{~h}$; Table 1b) in these upper Eocene Formations indicate that the sediments were deposited in oxic to oxygen-poor environments. $\mathrm{Pr} / \mathrm{Ph}$ ratio is useful as a geochemical in- dicator of the depositional environment redox condition (Didyk et al., 1978). Low $\mathrm{Pr} / \mathrm{Ph}$ ratios $(<1)$ are associated with anoxic conditions, values between 1 and 3 indicate sub-oxic conditions, and high $\mathrm{Pr} / \mathrm{Ph}$ ratios $(>3)$ indicate oxic environments containing inputs of vascular plants (Didyk et al., 1978; Powell, 1988; Peters and Moldowan, 1993). The $\mathrm{Pr} / \mathrm{Ph}$ ratios in the Phase-II coals (0.71-4.63; Table 1b) suggest a spectrum from oxygenpoor to oxic environments, whereas the single fresh PhaseI coaly shale (9.09 in A2-52) indicates an oxic environment. Low concentrations of pristane and phytane, and relatively high $\mathrm{Pr} / n-\mathrm{C}_{17}$ ratio (Table $1 \mathrm{~b}$ ) may indicate immature OM (e.g., Dzou et al., 1995; Hughes et al., 1995; Koopmans et al., 1999). For the weathered samples, low concentrations of pristane and phytane and low $\mathrm{Pr} / \mathrm{Ph}$ ratios are additionally caused by decomposition/ evaporation during the weathering. Slightly elevated homohopane oxic-anoxic index values $(0.01-0.24)$ in the Phase-II coals further suggest a range from oxic to oxygen-poor environments (Fig. 5h), because the homohopane ratio has been observed to increase with a decrease in dissolved oxygen (anoxia $>0.2$; Waseda and Nishita, 1998). The homohopane index values of the fresh samples show a negative curvilinear negative correlation with $\mathrm{Pr} / \mathrm{Ph}$ (Fig. 7d). Therefore, we consider the $\mathrm{Pr} / \mathrm{Ph}$ ratios of fresh coals and coaly shales to be effective as an oxic/anoxic indicator. The $\mathrm{C}_{31}-\mathrm{C}_{33}$ homohopanes are enriched in all samples with very low $\mathrm{C}_{35}$ homohopane. The Phase-II coals are slightly richer in $\mathrm{C}_{35}$ homohopane, indicating oxygen-poor fresh water environment (fresh water $\mathrm{C} / \mathrm{S}$ ratio $>5$ ), whereas the Phase-I coaly shale shows oxic condition.

In the unweathered samples the $\mathrm{Pr} / \mathrm{Ph}$ ratios exhibit negative correlation with $n-\mathrm{C}_{20-25} /$ total $n$-alkanes (Fig. $7 \mathrm{a})$, and positive correlation with sterane $\mathrm{C}_{29}$ / $\left(\mathrm{C}_{27}+\mathrm{C}_{28}+\mathrm{C}_{29}\right.$ ) (Fig. 7b) and HI (Fig. 7c). We suggest that these relationships imply that aquatic plants and vascular plant material with high $\mathrm{HI}$ was deposited under oxic conditions. Very high $\mathrm{Pr} / n-\mathrm{C}_{17}$ values (4.80-9.86; Table $1 b)$ in the unweathered coals and coaly shale imply that they were deposited in inland peat swamps and/or in highbiodegradation conditions, because $\mathrm{Pr} / n-\mathrm{C}_{17}$ values $>1$ generally indicate inland peat swamp environments (Amijaya and Littke, 2005) and active biodegradation (e.g., Waseda and Nishita, 1998). All of the studied samples are very likely to have been deposited in inland peat swamps, with associated oxic to oxygen-poor fresh water environments.

\section{Paleoclimate}

The Upper Eocene coals and coaly shales contain relatively abundant perylene, which is regarded as a biogenic product thought by some authors to be generated from perylenequinone pigments during early diagenesis 


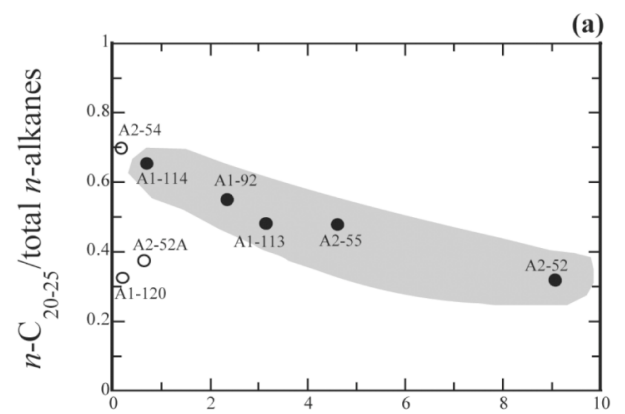

(b)
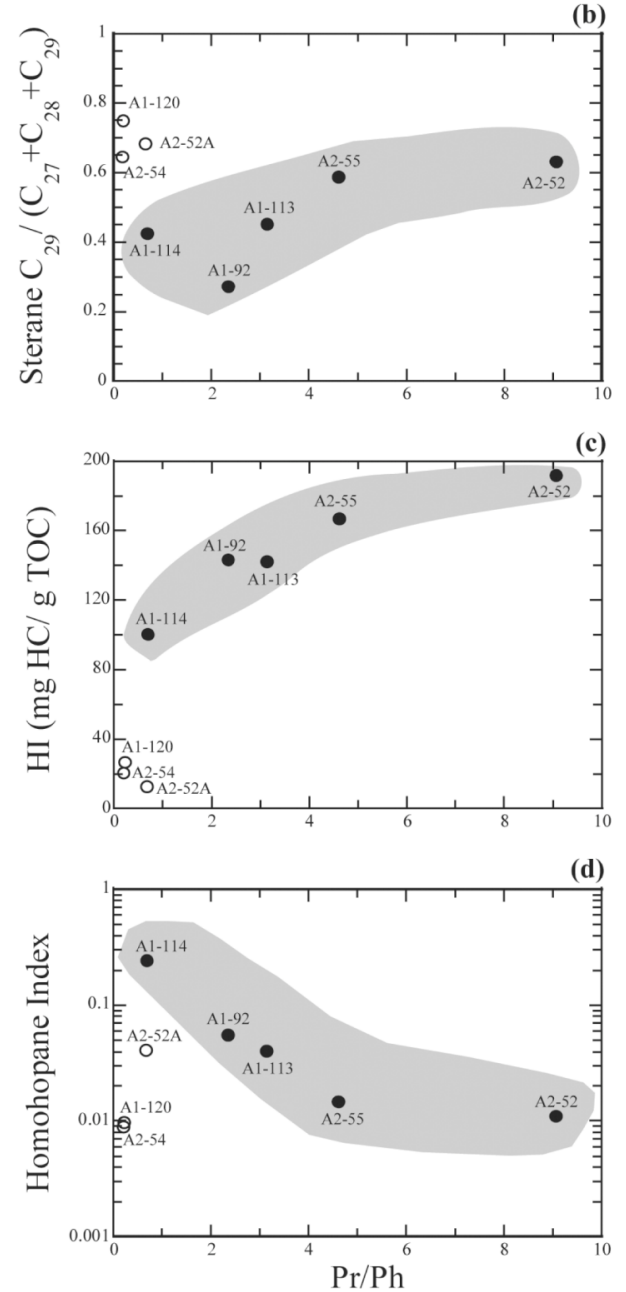

- unweatherec $\circ$ weathered

Fig. 7. Cross plots of (a) Pr/Ph vs. $n-C_{20-25} /$ total $n$-alkanes (b) Pr/Ph vs. sterane $C_{29} /\left(C_{27}+C_{28}+C_{29}\right)$, and (c) Pr/Ph vs. HI, and (d) $\mathrm{Pr} / \mathrm{Ph}$ vs. homohopane index, showing hydrocarbon generation, source of $O M$, and depositional environments for the Upper Eocene coals and coaly shales. Open circle data points indicate weathered samples; shaded zones illustrate the broad correlations in unweathered samples.

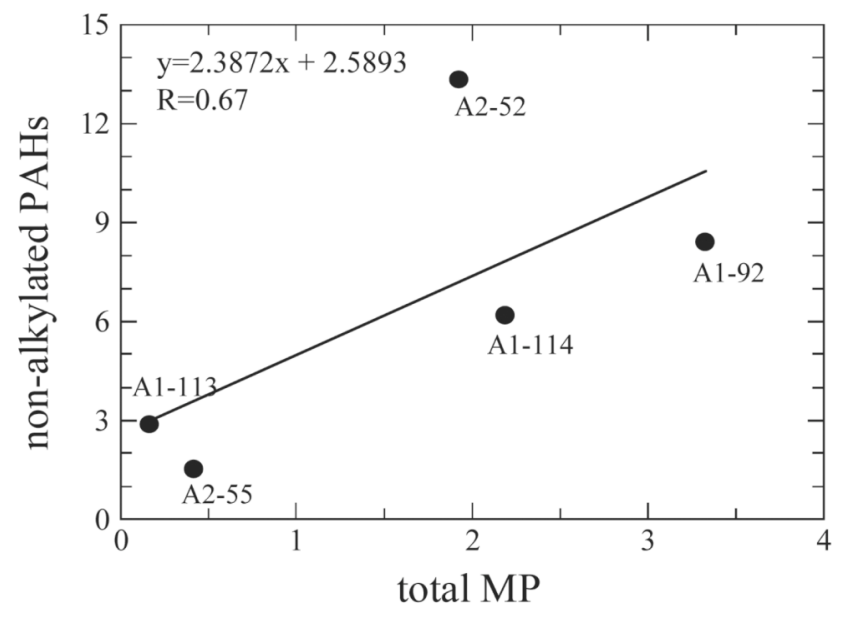

Fig. 8. Cross-plot of the non-alkylated hydrocarbons against the total MP (alkylated hydrocarbons) for the unweathered coals and coaly shale.

(Wakeham et al., 1980; Budzinski et al., 1997; Silliman et al., 1998; Jiang et al., 2000). Perylene is also considered to originate from wood-degrading fungi (Grice $e t$ al., 2009; Suzuki et al., 2010; Marynowski et al., 2013), and is predominantly found in humid and minimumoxygen environments (Aizenshtat, 1973). Perylene can therefore be considered to be a useful marker of humid/ wet climatic conditions (Grice et al., 2009; Suzuki et al., 2010). In the present study, the Phase-I coaly shale A252 contains abundant gymnosperm markers, and is also enriched in perylene (Table 2; Fig. 5e). This perylene could thus have been generated from wood-degrading fungi in a humid climate. Moist conditions also favour the growth of coniferous trees in subtropical rain forests. Perylene concentrations gradually decrease in the PhaseII coals, suggesting that climatic condition gradually changed from humid to relatively dry. Shift of climate from wet (humid) to dry (warm) could also account for the change in origin of the OM from gymnosperm-rich Phase-I (coaly shales) to angiosperm-rich Phase-II (coals).

Values of $>0.5$ for the ratio Fluoranthene/ (Fluoranthene+Pyrene) $(\mathrm{Fla} /(\mathrm{Fla}+\mathrm{Py}))$ are representative indicators of wildfire (e.g., Yunker et al., 2002). Only the uppermost coal (A1-92) has a Fla/(Fla+Py) ratio greater than $0.5(0.74$, Table 2), suggesting the occurrence of combustion in wildfire in this part of the succession. This is compatible with the estimation of dry climate in PhaseII. The other non-alkylated PAHs such as BaAn, Chry, Tpn, Bflas, BePy and BaPy could be diagenetic products formed from original coals and coaly shales, because their concentrations show positive correlation with MP $(R=$ 0.67, Fig. 8). Alkyl-substituted PAHs such as MP are largely dominated (Table 2 ) by those produced by diagenesis rather than by fire (Liu et al., 2005). 


\section{Characteristics as gas/oil source rocks}

Coal is known to be a source rock with gasgenerating potential (Tissot and Welte, 1984). The oxidizing facies can favour a tendency to be gas prone, rather than oil prone. The OM in the Late Eocene sediments of the present study is characterized as immature, as noted above $\left(R_{o}=0.26-0.42 \%\right.$ : Table $\left.1 \mathrm{a}\right)$. We determined the potential of hydrocarbon generation as source rocks by pyrolysis $\mathrm{S}_{2}$ yields, according to Peters and Cassa (1994). The $S_{2}$ values are relatively high (16.4-57.3 mg HC/g rock: Table 1a) in the fresh upper Eocene coals and coaly shale, suggesting good to excellent hydrocarbon generating potential.

According to Hunt (1991), hydrogen-rich coals containing resinous plants can generate liquid hydrocarbons, whereas hydrogen-poor coals can generate gas. Although most samples of the present study are probably related to gas-prone Type III and gas/oil-prone Type II and Type III kerogens, the high $\mathrm{HI}$ and low OI values for the coals (A1-92, A1-113 and A2-55; Table 1a) and the fresh coaly shale (A2-52) suggest the potential to generate some volumes of liquid hydrocarbons as well as gas. The weathered samples with low HI (12-26 mg HC/g TOC) and very high OI (137-212 $\mathrm{mg} \mathrm{CO}_{2} / \mathrm{g}$ TOC) compared to the unweathered samples with high HI (100-191 mg HC/g TOC) and low OI (28-107 $\mathrm{mg} \mathrm{CO}_{2} / \mathrm{g}$ TOC) indicate that hydrocarbon generation potential was decreased to about one tenth of the original value by moderate weathering. The weathered coaly shales, therefore, may have had good potential for hydrocarbon generation before weathering. The late Eocene samples show good source rock quality, with potential generation of liquid/gas hydrocarbons. Khin (1991) reported that source rocks in the CMB must lie deeper than $c a .3 \mathrm{~km}$, because samples taken from the basin at about that depth have low maturity, with $R_{o}$ values of $0.5 \%$. Curiale et al. (1994) suggested that Paleogene and Early Oligocene source rocks in the deeply-buried parts of the CMB have probably reached the minimum thermal maturity for hydrocarbon generation. Consequently, upper Eocene sediments which are even more favourable for hydrocarbon generation may thus occur in the deeper parts of the basin, compared to those present at its margins.

\section{CONCLUSIONS}

(1) Four coal seams containing 23-58 wt $\%$ TOC (PhaseII) were deposited after four coaly shale seams containing 2-8 wt $\%$ TOC (Phase-I). Moderate weathering was recognized in three coaly shales (A2-54, A2-52A, A1-120) containing $<8 \mathrm{wt} \%$ TOC, based on microscopic identification of weathering rims, fine cracks, and hole structures in vitrinite.

(2) The weathered coaly shale samples are characterized by very low $\mathrm{Pr} / \mathrm{Ph}(<0.7)$, high $T_{\max }\left(435-451^{\circ} \mathrm{C}\right)$, low HI (12-26 mg HC/g TOC), very high OI (137-212 mg $\mathrm{CO}_{2} / \mathrm{g}$ TOC) and decreased long chain $n$-alkanes $\left(>n-\mathrm{C}_{20}\right)$ bonded to kerogens. These results suggest that hydrocarbon generation potentials of oil/gas source rocks are decreased to about one tenth of the original value by moderate weathering. However, free $n$-alkanes, biomarkers such as steranes and triterpanes, and $\delta^{13} \mathrm{C}$ ratios of kerogen were not affected.

(3) Fresh samples are characterized by a mixture of Type II and Type III kerogens. Hydrocarbon generation potential of these gas-prone coals and coaly shales in the CMB is reasonably good, based on values of almost $200 \mathrm{mg}$ $\mathrm{HC} / \mathrm{g}$ TOC (HI).

(4) Facies change from the Phase-I coaly shales to the Phase-II coals was accompanied by changes in the origin of the organic matter. The coaly shales contain abundant gymnosperm biomarkers such as retene and 1,7-DMP. $\mathrm{Pr} /$ $\mathrm{Ph}$ ratios (0.71-9.09) from unweathered samples show a negative correlation with the homohopane index and $n$ $\mathrm{C}_{20-25} /$ total $n$-alkanes. $\mathrm{Pr} / \mathrm{Pr}$ ratios also show positive correlation with $\mathrm{HI}$ and sterane $\mathrm{C}_{29} /\left(\mathrm{C}_{27}+\mathrm{C}_{28}+\mathrm{C}_{29}\right)$.

In the Phase-I succession, unweathered Pondaung coaly shale (A2-52) exhibits high $\mathrm{Pr} / \mathrm{Ph}$ ratio (9.1), moderate $\mathrm{Ts} / \mathrm{Tm}$ ratio, predominance of $\mathrm{C}_{29}$ steranes, high CPI (2.22), slightly enriched sulfur content (1.14 wt \%), low $\mathrm{C}_{35}$ homohopane index and $n$ - $\mathrm{C}_{20-25} /$ total $n$-alkanes, indicating that it was mainly derived from terrestrial waxy plant materials with a minor input of bacteria and aquatic plants, and deposited in a peat swamp in a coastal plain or deltaic setting under oxic conditions.

The Phase-II coals show abundant contribution of angiosperm vegetation as oleanane content and oleanane/ $\mathrm{C}_{30}$ hopane ratio. The coals have low to relatively high $\mathrm{Pr} / \mathrm{Ph}$ values (0.71-4.63), low to relatively high Ts/Tm ratios, enrichment of $\mathrm{C}_{29}$ steranes in Pondaung coals (A1113, A1-114, A2-55) and high $\mathrm{C}_{28}$ sterane in Yaw coal (A1-92), low to high CPI values (1.2-2.1), low to high sulfur contents (0.09-3.95 wt \%), $\mathrm{C}_{35}$ homohopane index and $n$ - $\mathrm{C}_{20-25} /$ total $n$-alkanes values averaging 0.54 . These results imply that the source of the OM was mainly terrestrial herbaceous vegetation and/or aquatic plants, preserved in oxic to oxygen-poor environments in peat swamps associated with an estuarine/fluvial-deltaic setting. The Yaw coal was probably affected by subsequent sea level rise.

(5) $\delta^{13} \mathrm{C}$ values of all samples range from $-24.6 \%$ to $-26.5 \%$, suggesting variable contributions of gymnosperm and angiosperm vegetation. Angiosperm deposition is especially well-preserved in the two uppermost coals. Concentrations of conifer-derived 1,7 DMP are higher in samples with high HI (Phase-I coaly shale A252, and Phase-II coals A1-114 and A2-55). Wax-rich vascular plants are predominant in the Phase-I coaly shales, 
based on $n-\mathrm{C}_{29} / n-\mathrm{C}_{19}$ alkane ratios of $>1.5$ and $n-\mathrm{C}_{20-25} /$ total $n$-alkanes ratio averaging 0.43 . These associations suggest that high hydrocarbon generation potential in the coaly shales can be attributed to resinous vascular plant origin.

(6) Higher perylene abundances in Phase-I coaly shales decreasing into the Phase-II coals suggest a slowly alternating shift of climate from wet (humid/seasonal) to dry (warm) in the western margin of the CMB in the upper Eocene, leading to floral changes.

(7) Vitrinite reflectance $\left(R_{o}: 0.26-0.42 \%\right)$ and biomarker maturity parameters for all samples yield thermally immature organic matter.

(8) A record of significant wildfire $(\mathrm{Fla} /(\mathrm{Fla}+\mathrm{Py})=0.74)$ was recognized only in the late stage of Phase-II.

Acknowledgments-We are grateful to U Than Htay (Union Minister for Ministry of Energy, Myanmar), who gave permission for the senior author (EMH) to undertake a doctoral study and to conduct this work. We also thank U Htun Nyunt Oo (Asst. Executive Geologist, Myanma Oil and Gas Enterprise) and U Win Naing (Asst. Geologist, MOGE) for their help and discussion during fieldwork. Special thanks are expressed to U Aung Kyaw Htoo (Deputy Director, Ministry of Energy) for his encouragement. We also thank Dr. J. A. Curiale, an anonymous reviewer and Editor Dr. T. Yamanaka for their constructive and valuable comments on the manuscript. The study was supported by a grant from the Ministry of Education, Science and Culture of Japan (to EMH).

\section{REFERENCES}

Aizenshtat, A. (1973) Perylene and its geochemical significance. Geochim. Cosmochim. Acta 37, 559-567.

Amijaya, H. and Littke, R. (2005) Microfacies and depositional environment of Tertiary Tanjung Enim low rank coal, South Sumatra Basin, Indonesia. Int. J. Coal Geol. 61, 197-221.

Armstroff, A., Wilkes, H., Schwarzbauer, J., Littke, R. and Horsfield, B. (2006) Aromatic hydrocarbon biomarkers in terrestrial organic matter of Devonian to Permian age. Palaeogeog. Palaeoclim. Palaeoecol. 240, 253-274.

Bechtel, A., Gruber, W., Sachsenhofer, R. F., Gratzer, R., Lücke, A. and Püttmann, W. (2003) Depositional environment of the Late Miocene Hausruck lignite (Alpine Foreland Basin): insights from petrography, organic geochemistry, and stable carbon isotopes. Int. J. Coal Geol. 53, 153-180.

Bender, F. (1983) Geology of Burma. Borntraeger, Berlin, 293 pp.

Berner, R. A. (1984) Sedimentary pyrite formation: An update. Geochim. Cosmochim. Acta 48, 605-615.

Berner, R. A. and Raiswell, R. (1984) C/S method for distinguishing freshwater from marine sedimentary rocks. Geology 12, 365-368.

Böcker, J., Littke, R., Hartkopf-Fröder, C., Jasper, K. and Schwarzbauer, J. (2013) Organic geochemistry of Duckmantian (Pennsylvanian) coals from the Ruhr Basin, western Germany. Int. J. Coal Geol. 107, 112-126.
Budzinski, H., Jones, I., Bellocq, J., Piérard, C. and Garrigues, P. (1997) Evaluation of sediment contamination by polycyclic aromatic hydrocarbons in the Gironde estuary. Mar. Chem. 58, 85-97.

Chhibber, H. L. (1934) The Geology of Burma. Macmillan, London, $538 \mathrm{pp}$.

Copard, Y., Disnar, J. R., Becq-Giraudon, J. F. and Boussafir, M. (2000) Evidence and effects of fluid circulation on organic matter in intramontane coalfields (Massif Central, France). Int. J. Coal Geol. 44, 49-68.

Copard, Y., Disnar, J. R., Becq-Giraudon, J. F. and Boussafir, M. (2002) Erroneous maturity assessment given by $T_{\max }$ and HI Rock-Eval parameters on highly mature weathered coals. Int. J. Coal Geol. 49, 57-65.

Cranwell, P. A. (1977) Organic geochemistry of Camloch (Sutherland) sediments. Chem. Geol. 20, 205-221.

Cranwell, P. A., Eglinton, G. and Robinson, N. (1987) Lipids of aquatic organisms as potential contributors to lacustrine sediments-II. Org. Geochem. 11, 513-527.

Curiale, J. A., Kyi, P., Collins, I. D., Din, A., Nyein, K., Nyunt, M. and Stuart, C. J. (1994) The central Myanmar (Burma) oil family-composition and implications for source. Org. Geochem. 22, 237-255.

Davis, J. B. (1968) Paraffinic hydrocarbons in the sulfatereducing bacterium Desulfovibriodesulfuricans. Chem. Geol. 3, 155-160.

De Souza, D. B., Machado, K. S., Froehner, S., Scapulatempo, C. F. and Bleninger, Y. (2011) Distribution of $n$-alkanes in lacustrine sediments from subtropical lake in Brazil. Chemie der Erde 71, 171-176.

Del Rio, J. C., Gonzalez-Vila, F. J. and Martin, F. (1992) Variation in the content and distribution of biomarkers in two closely situated peat and lignite deposits. Org. Geochem. 18, 67-78.

Didyk, B. M., Simoneit, B. R. T., Brassel, S. C. and Eglinton, G. (1978) Organic geochemical indicators of palaeonvironmental conditions of sedimentation. Nature 272, 216-222.

Dzou, L. I. P., Noble, R. A. and Senftle, J. T. (1995) Maturation effects on absolute biomarker concentration in a suite of coals and associated vitrinite concentrates. Org. Geochem. 23, 681-697.

Fabiańska, M. J., Ćmiel, S. R. and Misz-kennan, M. (2013) Biomarkers and aromatic hydrocarbons in bituminous coals of Upper Silesian Coal Basin: Example from 405 coal seam of the Zaleskie Beds (Poland). Int. J. Coal Geol. 107, 96111.

Ficken, K. J., Li, B., Swain, D. L. and Eglinton, G. (2000) An $n$-alkane proxy for the sedimentary input of submerged/ floating freshwater aquatic macrophytes. Org. Geochem. 31, 745-749.

Grice, K., Lu, H., Atahan, P., Asif, M., Hallmann, C., Greenwood, P., Maslen, E., Tulipani, S., Williford, K. and Dodson, J. (2009) New insights into the origin of perylene in geological samples. Geochim. Cosmochim. Acta 73, 6531-6543.

Hall, R. and Morley, C. K. (2004) SundalandBasins.Continent Ocean Interactions within East Asian Marginal Seas (Clift, P., Wang, X., Kuhnt, W. and Hayes, D., eds.), Amer. Geophys. Union, Geophysical Monograph Series 149, 55- 
85.

Haq, B. U., Hardenbol, J. and Vail, P. R. (1987) Chronology of fluctuating sea levels since the Triassic. Science 235, 11561167.

Huang, W. Y. and Meinschein, W. G. (1978) Sterols in sediments from Baffin Bay, Texas. Geochim. Cosmochim. Acta 42, 1391-1396.

Huang, W. Y. and Meinschein, W. G. (1979) Sterols as ecological indicators. Geochim. Cosmochim. Acta 43, 739-745.

Hughes, W. B., Holba, A. G. and Dzou, L. I. P. (1995) The ratios of dibenzothiophene to phenanthrene and pristane to phytane as indicators of depositional environment and lithology of petroleum source rocks. Geochim. Cosmochim. Acta 59, 3581-3598.

Hunt, J. M. (1991) Generation of gas and oil from coal and other terrestrial organic matter. Org. Geochem. 17, 673680.

Jiang, C., Alexander, R., Kagi, R. I. and Murray, A. P. (2000) Origin of perylene in ancient sediments and its geological significance. Org. Geochem. 31, 1545-1559.

Kawka, O. E. and Simoneit, B. R. T. (1990) Polycyclic aromatic hydrocarbons in hydrothermal petroleums from the Guaymas Basin spreading center. Appl. Geochem. 5, 1727.

Khin, J. A. (1991) Hydrocarbon-producing formations of Salin, Irrawaddy, and Martaban Basins, Myanmar (Burma). Society of Petroleum Engineers Asia-Pacific Conference, Perth, Australia, November 4-7, 1991; Conference Proceedings, p. 245-258.

Killops, S. and Killops, V. (2005) Introduction to Organic Geochemistry. 2nd ed., Blackwell Publishing, U.K., 393 pp.

Koopmans, M. P., Rijpstra, W. I. C., Klapwijk, M. M., de Leeuw, J. W., Lewan, M. D. and Sinninghe Damsté, J. S. (1999) A thermal and chemical degradation approach to decipher pristane and phytane precursors in sedimentary organic matter. Org. Geochem. 30, 1089-1104.

Liu, G. Q., Zhang, G., Li, X. D., Li, J., Peng, X. Z. and Qi, S. H. (2005) Sedimentary record of polycyclic aromatic hydrocarbons in a sediment core from the Pearl River Estuary, South China. Mar. Pollut. Bull. 51, 912-921.

Lücke, A., Helle, G., Schleser, G. H., Figueiral, I., Mosbrugger, V., Jones, T. P. and Rowe, N. P. (1999) Environmental history of the German Lower Rhine Embayment during the Middle Miocene as reflected by carbon isotopes in brown coal. Palaeogeog. Palaeoclim. Palaeoecol. 154, 339-352.

Martínez, M. and Escobar, M. (1995) Effect of coal weathering on some geochemical parameters. Org. Geochem. 23, 253261.

Marynowski, L., Smolarek, J., Bechtel, A., Philippe, M. and Kurkiewicz, S. (2013) Perylene as an indicator of conifer fossil wood degradation by wood-degrading fungi. Org. Geochem. 59, 143-151.

Meyers, P. A. (1994) Preservation of elemental and isotopic source identification of sedimentary organic matter. Chem. Geol. 113, 289-302.

Meyers, P. A. (1997) Organic geochemical proxies of paleoceanographic, paleolimnologic, and paleoclimatic processes. Org. Geochem. 27, 213-250.

Meyers, P. A. and Ishiwatari, R. (1993) Lacustrine organic geochemistry-an overview of indicators of organic matter sources and diagenesis in lake sediments. Org. Geochem. 20, 867-900.

Moldowan, J. M., Dahl, J., Huizinga, B. J., Fago, F. J., Hickey, L. J., Peakman, T. M. and Taylor, D. W. (1994) The molecular fossil record of oleanane and its relation to angiosperms. Science 265, 768-771.

Mrkić, S., Stojanović, K., Kostić, A., Nytoft, H. P. and Šajnović, A. (2011) Organic geochemistry of Miocene source rocks from the Banat Depression (SE Pannonian Basin, Serbia). Org. Geochem. 42, 655-677.

Myint, K. K. and Soe, K. (1977) Geology report on TilinGangaw Area: Myanma Oil Corporation Report, K.K.M.2, K.S.1.

Nakamura, H., Sawada, K. and Takahashi, M. (2010) Aliphatic and aromatic terpenoid biomarkers in Cretaceous and Paleogene angiosperm fossils from Japan. Org. Geochem. 41, 975-980.

Noble, R. P., Alexander, R., Kagi, R. I. and Knox, J. (1986) Identification of some diterpenoid hydrocarbons in petroleum. Org. Geochem. 10, 825-829.

Nott, C. J., Xie, S., Avsejs, L. A., Maddy, D., Chambers, F. M. and Evershed, R. P. (2000) n-Alkane distributions in ombrotrophic mires as indicators of vegetation change related to climate variation. Org. Geochem. 31, 231-235.

Otto, A. and Simoneit, B. R. T. (2001) Chemosystematics and diagenesis of terpenoids in fossil conifer species and sediment from the Eocene Zeitz Formation, Saxony, Germany. Geochim. Cosmochim. Acta 65, 3505-3527.

Otto, A., Walter, H. and Püttmann, W. (1997) Sesqui- and diterpenoid biomarkers preserved in Taxodium-rich Oligocene oxbow lake clays, Weisselster basin, Germany. Org. Geochem. 26, 105-115.

Otto, A., Simoneit, B. R. T. and Rember, W. C. (2003) Resin compounds from the seed cones of three fossil conifer species from the Miocene Clarkia flora, Emerald Creek, Idaho, USA, and from related extant species. Rev. Palaeobot. Palynol. 126, 225-241.

Peters, K. E. (1986) Guidelines for evaluating petroleum source rock using programmed pyrolysis. AAPG Bull. 70, 318-329.

Peters, K. E. and Cassa, M. R. (1994) Applied source rock geochemistry. The Petroleum System-From Source to Trap (Magoon, L. B. and Dow, W. E., eds.), AAPG Memoir 60, 93-120.

Peters, K. E. and Moldowan, J. M. (1993) The Biomarker Guide: Interpreting Molecular Fossils in Petroleum and Ancient Sediments. Prentice Hall, New Jersey, 363 pp.

Peters, K. E., Walters, C. C. and Moldowan, J. M. (2005) The Biomarker Guide. 2nd ed., Prentice Hall, New Jersey, 1155 pp.

Petsch, S. T., Berner, R. A. and Eglinton, T. I. (2000) A field study of the chemical weathering of ancient sedimentary organic matter. Org. Geochem. 31, 475-487.

Philp, R. P. and Gilbert, T. D. (1986) Biomarker distributions in Australian oils predominantly derived from terrigenous source material. Org. Geochem. 10, 73-84.

Piedad-Sánchez, N., Suárez-Ruiz, I., Martínez, L., Izart, A., Elie, M. and Keravis, D. (2004) Organic petrology and geochemistry of the Carboniferous coal seams from the 
Central Austrian Coal Basin (NW Spain). Int. J. Coal Geol. 57, 211-242.

Pivnik, D. A., Nahm, J., Tucker, R. S., Smith, G. O., Nyein, K., Nyunt, M. and Maung, P. H. (1998) Polyphase deformation in a fore-arc/back-arc basin, Salin sub-basin, Myanmar (Burma). AAPG Bull. 82, 1837-1856.

Powell, T. G. (1988) Pristane/phytane ratio as environmental indicator. Nature 333, 604

Radke, M., Willsch, H. and Leythaeuser, D. (1982) Aromatic components of coal: relation of distribution pattern to rank. Geochim. Cosmochim. Acta 46, 1831-1848.

Seifert, W. K. and Moldowan, J. M. (1978) Applications of steranes, terpanes, and monoaromatics to the maturation, migration, and source of crude oils. Geochim. Cosmochim. Acta 42, 77-95.

Silliman, J. E., Meyers, P. A. and Eadie, B. J. (1998) Perylene: an indicator of alteration processes or precursor materials? Org. Geochem. 29, 1737-1744.

Simoneit, B. R. T. (2005) A review of current applications of mass spectrometry for biomarker/molecular tracer elucidation. Mass Spec. Rev. 24, 719-765.

Simoneit, B. R. T., Grimalt, J. G., Wang, T. G., Cox, R. E., Hatcher, P. G. and Nissenbaum, A. (1986) Cyclicterpenoids of contemporary resinous plant detritus and fossil woods, ambers and coals. Org. Geochem. 10, 877-889.

Stamp, L. D. (1934) Natural gas fields of Burma. AAPG Bull.
18, 315-326.

Stefanova, M., Kortenski, J., Zdravkov, A. and Marinov, S. (2013) Paleoenvironmental settings of the Sofia lignite basin: Insights from coal petrography and molecular indicators. Int. J. Coal Geol. 107, 45-61.

Suzuki, N., Yessalina, S. and Kikuchi, T. (2010) Probable fungal origin of perylene in Late Cretaceous to Paleogene terrestrial sedimentary rocks of northeastern Japan as indicated from stable carbon isotopes. Org. Geochem. 41, 234-241.

Tissot, B. P. and Welte, D. H. (1984) Petroleum Formation and Occurrence. 2nd ed., Springer-Verlag, Berlin, 699 pp.

Tun, P. (1968) Stratigraphic measurements of Western outcrops-Kyauktu-Laungshe Area: Myanma Oil Corporation Report, P.T.1.

Wakeham, S. G., Schaffner, C. and Giger, W. (1980) Polycyclic aromatic hydrocarbons in Recent lake sediments-II. Compounds derived from biogenic precursors during early diagenesis. Geochim. Cosmochim. Acta 44, 415-429.

Waseda, A. and Nishita, H. (1998) Geochemical characteristics of terrigenous- and marine-sourced oils in Hokkaido, Japan. Org. Geochem. 28, 27-41.

Yunker, M. B., Macdonald, R. W., Vingarzan, R., Mitchell, R. H., Goyette, D. and Sylvestre, S. (2002) PAHs in the Fraser River basin: a critical appraisal of $\mathrm{PAH}$ ratios as indicators of PAH source and composition. Org. Geochem. 33, 489515. 